UNIVERSIDADE DE SÃO PAULO

FACULDADE DE FILOSOFIA, LETRAS E CIÊNCIAS HUMANAS

DEPARTAMENTO DE LETRAS CLÁSSICAS E VERNÁCULAS

PROGRAMA DE PÓS-GRADUAÇÃO EM FILOLOGIA E LÍNGUA PORTUGUESA

ARNALDO REBELLO CAMARGO JUNIOR

\title{
A REALIZAÇÃO DO OBJETO DIRETO EM REFERÊNCIA AO INTERLOCUTOR
}

SÃO PAULO 


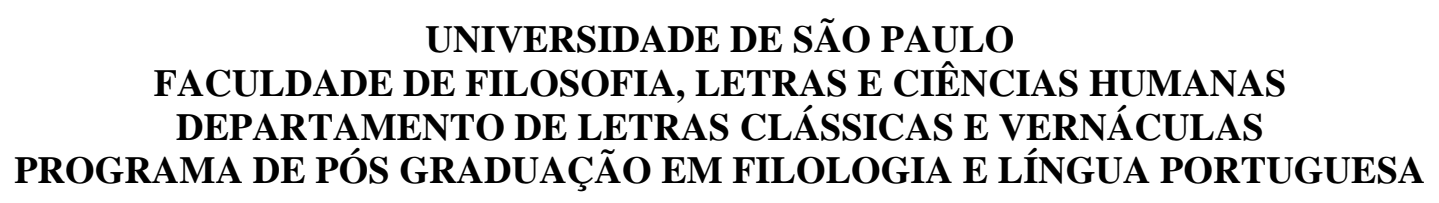

\section{A REALIZAÇÃO DO OBJETO DIRETO EM REFERÊNCIA AO INTERLOCUTOR}

\section{Arnaldo Rebello Camargo Junior}

Dissertação apresentada ao Programa de PósGraduação em Filologia e Língua Portuguesa, do Departamento de Letras Clássicas e Vernáculas da Faculdade de Filosofia, Letras e Ciências Humanas da Universidade de São Paulo, para obtenção do título de Mestre em Letras.

Orientadora: Prof ${ }^{\mathrm{a}}$. Dra ${ }^{\mathrm{a}}$. Marilza de Oliveira

\section{SÃO PAULO}


FOLHA DE APROVAÇÃO

\section{Arnaldo Rebello Camargo Junior A realização do objeto direto em referência ao interlocutor}

Dissertação apresentada ao Programa de PósGraduação em Filologia e Língua Portuguesa, do Departamento de Letras Clássicas e Vernáculas da Faculdade de Filosofia, Letras e Ciências Humanas da Universidade de São Paulo, para obtenção do título de Mestre em Letras.

Área de concentração: Filologia e Língua Portuguesa

Aprovado em:

Banca Examinadora

Prof. Dr.

Instituição: Assinatura:

Prof. Dr.

Instituição: Assinatura:

Prof. Dr.

Instituição: Assinatura:

Prof. Dr.

Instituição: Assinatura:

Prof. Dr.

Instituição: Assinatura: 
Dedico este trabalho a Arnaldo Rebello Camargo, exemplo de dignidade, caráter e bondade.

(in memoriam) 


\section{AGRADECIMENTOS}

Agradeço à Marilza de Oliveira, exemplo de dedicação à pesquisa acadêmica, pela sua paciência e orientação precisa.

À Instituição Marista, em especial ao Colégio Marista Nossa Senhora da Glória, pelo auxilio financeiro e pela concessão do espaço e tempo das aulas para aplicação de inúmeros testes que gerou, alem deste, outros trabalhos de pesquisa.

A todos aqueles que direta ou indiretamente, ajudaram na elaboração deste estudo. 


\section{RESUMO}

Propomos o estudo da realização do objeto direto no Português Brasileiro (PB) na referência ao interlocutor, a partir de um corpus formado essencialmente por textos produzidos por alunos do Ensino Fundamental II de uma escola particular da cidade de São Paulo. Estes textos consistem em uma proposta de redação direcionada à produção do objeto direto na referência ao interlocutor, orientados aos registros formal e informal da língua.

Objetivamos identificar o tipo de complemento produzido pelos alunos nos dois registros. Interessa-nos investigar, sobretudo, as formas pronominais acusativas de $2^{\mathrm{a}}$ pessoa bem como a posição dos clíticos para estabelecer diálogo com os trabalhos que tratam das formas pronominais acusativas de $3^{\mathrm{a}}$ pessoa. Para isto, utilizamos o método variacionista de análise quantitativa, conforme estabelecido por Labov, e já consagrado em inúmeros estudos.

Os resultados obtidos serão norteados pelas hipóteses descritas ao longo da introdução deste estudo, e a partir da confirmação de algumas e descarte de outras, buscaremos estabelecer uma adequação descritiva suficiente para comprovar o desaparecimento do clítico acusativo de $3^{\mathrm{a}}$ pessoa aplicado em referência ao interlocutor (Ramos 1999), substituído pela forma "te", ou para realinhar o clítico "o" no sistema pronominal da variedade paulistana do português brasileiro.

Palavras-Chave: Objeto direto, clítico, interlocutor, aprendizagem, especialização de formas. 


\begin{abstract}
The aim of this study of the effectiveness of the direct object in Brazilian Portuguese (BP) at the interlocutor's reference, from a corpus essentially made by texts produced by students from a private school at São Paulo city. These texts consist in a request for composition directed to the production of the direct object at the interlocutor's reference, guided to the formal and informal registers of the language.

The objective defined here is identifying the kind of complement that is produced by the students at the formal and informal registers. The main intention is investigate the second person accusatives pronominal forms as well as the clitics position, to establish connection with studies that work with the third person accusatives pronominal forms. In this sense, it was used the quantitative method of analysis, as establish by Labov, and already considerate in many studies.

The results will be guided by the hypotheses described at the introduction of this study and from the confirmation of some hypotheses and the discard of others there will be establish a suit descriptive sufficient to corroborate the useless of the third person accusative clitic applied at the interlocutor's reference (Ramos 1999), replaced by the form "te" or to align the clitic "o” at the pronominal system of varieties of the Brazilian Portuguese from São Paulo.
\end{abstract}

Keywords: direct object, second person, L2 input, forms specialization 


\section{SUMÁRIO}

INTRODUÇÃO

1 REVISÃO DA LITERATURA: OBJETO DIRETO 14

1.1 O QUADRO ATUAL DO SISTEMA PRONOMINAL DO PB 14

1.2 O ESTUDO DO OBJETO DIRETO CO-REFERENCIAL 16

1.3 A POSIÇÃO DOS CLÍTICOS EM PORTUGUÊS 18

1.4 A PERDA DO CLÍTICO ACUSATIVO “O” EM REFERÊNCIA AO INTERLOCUTOR 21

2 METODOLOGIA E PRESSUPOSTOS TEÓRICOS 27

2.1 PREPARAÇÃO DO CORPUS 27

2.1.1 Teste de Produção: Registro Formal 28

2.1.2 Teste de Produção: Registro Informal 29

2.2 LOCAL DE APLICAÇÃO DOS TESTES: COLÉGIO MARISTA NOSSA
SENHORA DA GLÓRIA

2.3 FATORES PARA ANÁLISE $\quad 32$

2.4 AQUISIÇÃO DA LINGUAGEM

2.5 HIPÓTESES SOBRE A APRENDIZAGEM DA ESCRITA 38

2.6 HIPERCORREÇÃO E ERRO 39

2.7 ESPECIALIZAÇÃO E SUBSTITUIÇÃO DE FORMAS 40

3 ANÁLISE DESCRITIVA DOS DADOS 43

3.1 PARTE I: MODALIDADE FORMAL 44

3.1.1 Realização do complemento verbal 44

3.1.2 Tipo de clítico na função de objeto direto em referência ao

3.1.3 Posição do clítico em relação à estrutura verbal 52

3.1.3.1 Verbos Simples $\quad 52$

3.1.3.2 Grupos Verbais $\quad 55$

3.1.4 Considerações finais sobre a modalidade formal $\quad 59$

3.2 PARTE II: MODALIDADE INFORMAL 61

3.2.1 Realização do complemento verbal 61

3.2.2 Tipo de clítico na função de objeto direto em referência ao interlocutor 64

3.2.3 Posição do clítico em relação à estrutura verbal 67

3.2.3.1 Verbos Simples $\quad 67$

3.2.3.2 Grupos Verbais $\quad 72$

$\begin{array}{ll}\text { 3.2.3.3 Ênclise, onset silábico e assimilação } & 78\end{array}$

3.2.4 Considerações finais sobre a modalidade informal $\quad 80$

3.3 DUPLICAÇÃO DO OBJETO

3.4 HIPERCORREÇÃO E ERRO

3.5 ESPECIALIZAÇÃO E SUBSTITUIÇÃO DE FORMAS

4 CONSIDERAÇÕ̂ES FINAIS

5 BIBLIOGRAFIA $\quad 92$ 


\section{Lista de tabelas}

Tabela 1 - Formas de objeto direto: número de ocorrências e percentual : 44 modalidade formal

Tabela 2 - Formas de objeto direto X séries escolares: modalidade formal 46

Tabela 3 - Tipo de clítico na função de objeto direto em referência ao 49 interlocutor: modalidade formal

Tabela 4 - Tipo de clítico por série escolar : modalidade formal 50

Tabela 5 - Tipo de clítico X posição com formas verbais simples: modalidade 52

formal

Tabela 6 - Tipo de clítico X Posição em grupos verbais: modalidade formal 56

Tabela 7 - Forma nominal do $2^{\circ}$ verbos nos grupos verbais X posição do 57

pronome clítico: modalidade formal

Tabela 8 - Formas de objeto direto: número de ocorrências e percentual : $\quad 61$

modalidade informal

Tabela 9 - Formas de objeto direto X séries escolares: modalidade informal 63

Tabela 10 - Tipo de clítico na função de objeto direto em referência ao 64

interlocutor: modalidade informal

Tabela 11 - Tipo de clítico por série escolar : modalidade informal 65

Tabela 12 - Tipo de clítico X posição com formas verbais simples: modalidade 67

informal

Tabela 13 - Forma nominal do $2^{\circ}$ verbos nos grupos verbais $\mathrm{X}$ Tipo de pronome 72

clítico: modalidade informal

Tabela 14 - Forma nominal do $2^{\circ}$ verbos nos grupos verbais $\mathrm{X}$ posição do pronome clítico: modalidade informal 


\section{Lista de gráficos}

Gráfico 1: Formas do objeto direto X série escolar: modalidade formal.

Gráfico 2: Tipo de clítico X série escolar: modalidade formal.

Gráfico 3: Formas de objeto direto X séries escolares: modalidade informal 


\section{INTRODUÇÃO}

A gramaticalização da forma "você" como pronome referencial de $2^{\mathrm{a}}$ pessoa tem sido indicada na literatura como a causa da perda do sujeito nulo no Português Brasileiro (Duarte, 1993, 1995, entre outros) e pela alteração do sistema pronominal do Português Brasileiro, como o uso residual do clítico acusativo de $3^{\mathrm{a}}$ pessoa (Duarte 1986) e como a substituição do clítico dativo "lhe" pela forma preposicionada “a/para ele” (Berlinck, 1996, 1997, 1999, entre outros).

As gramáticas normativa (Cunha e Cintra 1985) e descritiva (Neves 2000), por sua vez, não ficam alheias ao processo de mudança no sistema pronominal, visto que registram a função nominativa das formas "você” e "vocês” para a segunda pessoa do singular e plural, respectivamente, ao lado de “tu” e “vós”. Quanto às demais funções sintáticas, elegem a forma de $3^{\text {a }}$ pessoa “o” para o acusativo e "lhe” para o dativo. Partindo do pressuposto da correspondência das formas pronominais, estabelecem que o uso da forma nominativa "tu" implica na escolha da forma "te" para a função acusativa e dativa, ao passo que o uso da forma nominativa "você" implica no uso das formas "o" e "lhe" para os casos acusativo e dativo, respectivamente, em referência ao interlocutor. Tal correspondência se baseia no fato de que o pronome "você" estabelece concordância com a forma verbal de $3^{\mathrm{a}}$ pessoa.

A correspondência entre as formas pronominais prescritas pelas gramáticas, porém, não está em consonância com os trabalhos lingüísticos que mostram a perda dos clíticos de $3^{\mathrm{a}}$ pessoa. No caso específico da referência ao interlocutor, os trabalhos de Ramos (1999) e Oliveira (2003) assumem a recategorização de "lhe” que passa de dativo a acusativo, competindo com a forma de segunda pessoa “te”. De fato, "Ihe” tem sido atestado na fala de personagens nordestinos bem como na fala de personagens de época, em novelas.

Os trabalhos acima mencionados, além de não trazerem o peso do registro na realização do clítico em referência ao interlocutor, não discutem se a escola tem peso atuante 
na escolha do clítico "lhe” na função acusativa, ao introduzir o quadro pronominal. Nesse sentido, este trabalho tem por objeto de estudo, a realização do objeto direto em referência ao interlocutor, procurando observar a tipologia pronominal em função dos registros formal e informal e o peso da escola na escolha de uma forma ou de outra. Pretende-se, além disso, observar se os resultados obtidos para o clítico de terceira pessoa são válidos para o objeto direto que faz referência ao interlocutor. Assim sendo, objetivamos responder às seguintes questões, que devem nortear o trabalho:

1. Qual o tipo de realização do objeto direto na referência ao interlocutor?

2. Quando o objeto for pronominalizado em clítico, qual a forma preferencial utilizada na referência ao interlocutor?

3. Tendo em vista o foco no interlocutor, qual o peso que o registro (formal, informal) apresenta na escolha pronominal?

Para tanto, assumimos as seguintes hipóteses:

1. O clítico acusativo “o”, assim como no uso anafórico de $3^{\mathrm{a}}$ pessoa (Duarte 1986), também não é usado em referência ao interlocutor;

2. Os clíticos "te” e "lhe” são usados no registro informal e formal, respectivamente;

3. A escola municia o aluno com o clítico "lhe”, cujo uso no registro formal será resultado do processo de aprendizagem.

Além das questões e hipóteses acima, pretendemos analisar a posição dos clíticos em relação a verbos simples e grupo verbal com o objetivo de avaliar se o registro formal também incide na distribuição das formas pronominais em referência ao interlocutor. Hipotetizamos, assim, que a colocação pronominal não se pauta pelo tipo de registro. 
Esta dissertação está estruturada em quatro capítulos. O primeiro capítulo traz a revisão da literatura sobre o pronome em função acusativa; o segundo capítulo trata da metodologia e dos pressupostos teóricos. No terceiro capítulo, temos a análise dos dados. Este capítulo é dividido em duas partes: na primeira apresentamos os dados relativos à modalidade formal e na segunda tratamos dos dados relativos à modalidade informal do discurso. Por último, apresentamos as considerações finais do trabalho. 


\section{REVISÃO DA LITERATURA: OBJETO DIRETO}

Neste capítulo analisamos considerações e estudos anteriores sobre a realização do objeto direto no PB (com ênfase nos pronomes clíticos), de modo a evidenciar algumas idéias que contribuirão para o estudo que ora propomos. Buscaremos descrever o quadro atual das pesquisas sobre o preenchimento desta posição, quando ocorre com pronomes clíticos em contraposição com outras formas (Sintagma nominal, pronomes plenos e objeto nulo), verificando qual o tipo de pronome tônico mais ocorre nesta posição, assim como os fatores que estão contribuindo para as diferentes realizações. Isto servirá de embasamento para observarmos, também, as reais diferenças, no sistema pronominal, relativas ao preenchimento da posição de objeto direto de $3^{\mathrm{a}}$ pessoa e na referência ao interlocutor ( $2^{\mathrm{a}}$ pessoa).

\subsection{0 quadro atual do sistema pronominal do PB}

Observando os resultados dos estudos recentes acerca da descrição do sistema pronominal do PB contemporâneo, faremos um levantamento das principais características observadas para o estudo do sistema pronominal do PB e sua relação direta com o preenchimento da posição de objeto direto por tais estruturas, observando questões tais como a referencialidade, função e usos.

Inicialmente, podemos observar a forma "você", originalmente uma forma de $3^{\mathrm{a}}$ pessoa, que entra no sistema pronominal do PB no lugar da forma "tu” (Paredes Silva, 2003 apud Cruz, 2007), enfraquecendo a flexão verbal, quando este encontra-se na posição de sujeito (Torres-Morais \& Berlink, 2002). Isto gera um quadro no PB que pode ser associado à perda da força do clítico de $3^{\mathrm{a}}$ pessoa, de modo que haja a concorrência entre as formas 
pronominais tônicas “ele” e o clítico “o”, de função acusativa, uma vez que este tipo de clítico não está mais presente no input da criança, ao adquirir o PB como língua materna. Na função dativa, contamos ainda com a forma "Ihe”, que, pelos mesmo motivo que a forma "o", concorre com os pronomes tônicos (introduzidos por preposição "a”) “você” (na referência ao interlocutor) e “ele” (na referência à $3^{\mathrm{a}}$ pessoa do discurso).

Deste modo, com relação aos pronomes clíticos, podemos evidenciar o quadro proposto por Galves (2001) acerca das funções assumidas para cada forma clítica no PB, em que teríamos na função acusativa, a concorrências entre as formas "te”, "lhe” e “você”, e na função dativa, a concorrência entre as formas "lhe” e "a você", na referencia ao interlocutor. Quando a referência faz-se à $3^{\mathrm{a}}$ pessoa do discurso, na função acusativa teríamos as formas concorrentes “ele” e “o” para a função acusativa, e "a ele” na função dativa. Este quadro, no entanto, parece não ser estável (conforme veremos ainda neste capítulo, no estudo de Ramos, 1999), pois algumas destas formas parece ainda não contar com a estabilidade nos usos, uma vez que podem ser atestados diferentes realizações se contrastarmos a influencia das variações dialetais neste sentido.

Outro aspecto bastante importante a ser levantado, refere-se à colocação dos clíticos em relação aos verbos. Conforme Cruz (2007), em estudo contrastivo entre o PB e PE (Português Europeu), mostra que em contextos onde há a presença de algum elemento que seja atrator do clítico (advérbios, conjunções, etc), fazendo com que o pronome esteja na posição proclítica obrigatoriamente no $\mathrm{PE}$, nem sempre ocorre no $\mathrm{PB}$, e deste modo, observamos que a posição dos clíticos no PB é influenciada por outros fatores, além da presença de estruturas atratoras, independentemente do fato deste clítico estar frente a um verbo simples ou mesmo a um grupo verbal (estrutura com V1 aux. +V2), pois é comum verificarmos ocorrência do clítico interposto ao grupo verbal no $\mathrm{PB}$, fato que quase não se observa no PE. 
Ao que tudo indica, a ocorrência de ênclise em contextos em que deveria haver a próclise no PB é associada à escola, à aprendizagem formal que o indivíduo recebe, pois é neste contexto que os alunos aprendem a utilizar os clíticos, fora do contexto em que estes ocorrem na fala, de modo que a aprendizagem da escrita fornece ao indivíduo um outro sistema que entra em conflito com aquele adquirido em tenra idade.

\subsection{O estudo do objeto direto co-referencial}

Duarte (1986) fundamentou, inicialmente, sua pesquisa nas diferentes realizações do objeto direto anafórico na fala, em comparação ao que ocorre na língua escrita, visando verificar quais condicionamentos (lingüísticos, sociais ou estilísticos) devem estar atuando nesse processo, observando que não só os fatores lingüísticos formais (semânticos, sintáticos) interferem na variação dos diferentes tipos de preenchimento, mas também as atitudes subjetivas dos falantes, em relação às variedades padrão e informal em uso.

Dentre os elementos que preenchem a posição de argumento interno dos verbos transitivos diretos, temos os clíticos acusativos "o" como forma pronominal de $3^{\mathrm{a}}$ pessoa, sendo possível constatar-se, também, o preenchimento pelo dativo de terceira pessoa "lhe", e, justamente devido a este fato, a autora adota o fator escolaridade no lugar do nível sócioeconômico, pois constatou que os clíticos acusativos não são produzidos na fala de indivíduos analfabetos (ou de baixa escolaridade) o que remete ao fato de que estas estruturas são aprendidas, primeiramente, via instrução formal.

O estudo do objeto direto co-referente revelou a tendência crescente do clítico acusativo de terceira pessoa ser substituído por pronomes lexicais, sintagmas nominais anafóricos ou por categoria vazia sendo, para esta última, o traço [animado] o elemento 
principal, atuante, (conforme a escala de referencialidade) que motiva o aparecimento destas estruturas em dados contextos lingüísticos. O traço [+animado] do antecedente favorece o preenchimento do objeto, enquanto o traço [- animado] implicaria em uma forte tendência ao uso de categoria vazia na posição de objeto, independente dos outros fatores lingüísticos que estejam atuando nos dados levantados. Ressalte-se que o corpus em análise é constituído de inquéritos do português falado em São Paulo. Verificamos, então, como não só o traço [animado], mas também o traço [humano] são relevantes para determinar o tipo de variação das estruturas clíticas, pronominais e lexicais no preenchimento do objeto, o que pode levar à conseqüência de indicar um dos fatores que estaria gerando a mudança no sistema lingüístico, ou mesmo a competição entre gramáticas, neste mesmo sistema, do PB.

Com relação à análise dos fatores, Duarte constatou que os fatores sociolingüísticos mostraram-se igualmente importantes no que se refere ao preenchimento do objeto, pois a autora encontrou, em seus dados, evidências de que a escolaridade e a idade influenciam de modo determinante no tipo de realização do objeto, uma vez que os informantes mais velhos e de maior escolaridade tendem a utilizar mais a categoria vazia com o traço [+animado], enquanto o informante de escolaridade mais baixa, independentemente da faixa etária, tende a utilizar mais o pronome pleno no preenchimento do objeto. Com relação ao clítico, de modo geral, os informantes avaliam-no como uma variante estigmatizada em contextos informais, e justamente por isso, evitam sua utilização nestes contextos.

Na conclusão de seu trabalho, a autora atesta, ainda, uma evidente queda no uso de clíticos acusativos de $3^{\mathrm{a}}$ pessoa na fala, pois há uma tendência crescente no PB à utilização de pronomes plenos e SNs,. Deste modo, teríamos, então, um enfraquecimento da flexão de terceira pessoa, gerando a necessidade de marcar o tópico/sujeito nos casos de categoria vazia, pois estas categorias são geradas em uma posição argumental e são vinculadas em uma 
posição não-argumental, que, por sua posição inicial na frase, garante a vinculação e, consequentemente, um parâmetro de identificação para tais categorias vazias.

\subsection{A Posição dos Clíticos em Português}

Em Pagotto (1992), verificamos a análise da posição ocupada pelos clíticos nas sentenças do português do Brasil (PB) e no Português Europeu (PE) em perspectiva diacrônica, em sentenças constituídas por verbo-único e grupo verbal (locução verbal), com e sem a precedência de estruturas adverbiais (atrativas de próclise, para os clíticos em geral), buscando verificar quais fatores estariam atuando na configuração das sentenças em cada uma das respectivas variedades do Português. Suas conclusões principais acerca do PB incidem no fato de que, ao longo do tempo, esta variedade teria perdido o movimento do verbo e o movimento do clítico ao longo do tempo, o que não constatável no PE, reforçando a idéia da existência de duas gramáticas diferentes, fato este que já conta com alguma notoriedade nos estudos lingüísticos dos últimos anos.

Pagotto tem como objetivo desta análise partir da investigação da posição dos clíticos na comparação entre o PB e PE em perspectiva histórica para confirmar a hipótese de que as mudanças ocorridas nestas estruturas pronominais, a partir de traços morfológicos e sintáticos, revelam profundas e graduais mudanças na estrutura da língua portuguesa, e que isto, como reflexo, mostre:

a) Os padrões para distribuição das estruturas clítica no português atual; e 
b) As regras de movimento de constituintes no português. ${ }^{1}$

Buscando uma abordagem teórica viável para análise, Pagotto reproduz uma interessante hipótese, fundamentada nos pressupostos gerativistas, que consiste no tratamento geométrico e algébrico para explicar as diferentes distribuições dos clíticos na sentença.

A proposta geométrica procura explicar isto por uma visão puramente sintática, em que a ordem linear dos constituintes (conseqüentemente, o conceito de c-comando) e as regras de dominância imediata estariam regendo este processo, enquanto a proposta algébrica leva em consideração a natureza categorial e a estrutura lexical dos constituintes, e, por isso, é uma abordagem morfológica. Ambas as visões se complementam, no ponto de vista do movimento de verbos e de barreiras constituídas (proibições) para movimentos sintáticos, pois natureza categorial e dominância imediata são dois requisitos importantes para dar conta da explicação, mesmo que analítica, dos fenômenos ora analisados, o que leva imediatamente à reflexão sobre a categoria morfológica e função sintática dos clíticos; em outras palavras, seriam os clíticos afixos morfológicos ou núcleos lexicais?

Do ponto de vista morfológico, clíticos em próclise e em ênclise não fazem parte das mesmas categorias lexicais pois o clítico em próclise, configura-se como um afixo, em processo semelhante às da prefixação (por substituição), o que não altera a categoria lexical dos verbos, ao passo que o clítico em ênclise seria um adjunto em relação ao verbo. Partido destas considerações, Pagotto remete a Galves (1990), que afirma, então, que a próclise estaria ligada ao verbo por meio do núcleo funcional tempo (T) e a ênclise, por meio da concordância (Agr). No entanto, estas abordagens encontram inúmeros obstáculos para que sejam consideradas aqui válidas para explicar as diferentes distribuições dos clíticos (apesar

\footnotetext{
${ }^{1}$ Como nosso interesse na discussão elaborada por Pagotto corresponde somente aos padrões observados para o $\mathrm{PB}$, pretendemos descrever somente os resultados pertinentes a isto, descartando as comparações com os padrões do PE, quando isto não trouxer dados relevantes para nosso estudo.
} 
de consistirem em um aparato suficientemente bom para adequação descritiva), mas também não encontram obstáculos suficientes para que sejam descartados, o que nos leva a crer que ainda há muito trabalho a ser feito, para que se obtenha algum resultado concreto neste sentido.

O maior problema destas análises seria não levar em consideração a influência de fatores fonológicos e a falta de uma fundamentação teórica uniforme, que dê conta da explicação dos elementos que condicionam a posição dos clíticos na sentença, uma vez que, mesmo a observação do comportamento dos clíticos em perspectiva diacrônica (que mostram muitos elementos sociais e lingüísticos agindo nas regras de variação de uma determinada estrutura lingüística), revela fatos interessantes na evolução lingüística de tais estruturas, mas, por si mesmas, pouco esclarecem, no que concerne a uma forma de se explicar como e porquê se dá a distribuição de tais estruturas no momento atual, em relação às variedades estudadas.

Como resultado descritivo do contraste diacrônico entre o PB e o PB, em relação aos clíticos, o autor revela que, no PB:

a) a posição do verbo na sentença é o fator que mais fortemente condiciona a posição dos clíticos (ou seja, se o verbo é único ou locução, se a sentença é finita ou não);

b) existe uma grande tendência à próclise no que vem desde o século XVI;

c) as regras de movimento não dão conta de estabelecer a mobilidade do verbo e do clítico, assim estabelecendo que ambos são móveis na sentença;

d) em qualquer que seja a gramática analisada, o clítico deve estar necessariamente afixado a um núcleo funcional;

e) houve a perda do movimento de verbo e do movimento longo do clítico, e isto é afirmado com base no tratamento algébrico e geométrico dos clíticos; 
f) o português clássico apresenta um padrão de próclise bem próximo do PB atual.

Estas conclusões são bastante importantes para caracterizar os fenômenos lingüísticos relativos ao percurso diacrônico do PB e caracterizar o momento atual desta variedade. Observemos, no entanto, que a pesquisa de Pagotto (op. Cit.) não é conclusiva no que se refere ao estatuto categorial dos clíticos no $\mathrm{PB}$, sua natureza lexical e as regras que estariam interferindo em sua distribuição, de modo que faremos o contraste dos resultados deste estudo às hipóteses aventadas pelo autor e expostas até aqui.

\subsection{A perda do clítico acusativo “o” em referência ao interlocutor}

Em sua tese, Ramos (1999) analisa a forma dativa "lhe" em variedades do PB da região nordeste do Brasil, e seu uso em função acusativa, visando constatar uma possível reorganização no sistema pronominal do PB, observando assim as diferenças no uso da forma pronominal plena "ele" em contraste com o clítico "lhe". Estas formas estariam em competição, no preenchimento da posição de objeto direto, quando isto é feito por um elemento de traço [+pronominal], sobressaindo a forma "lhe" nas variedades do PB que ainda utilizam-se da forma "tu" (como nas variedades da região nordeste) em seu sistema. No entanto, é possível verificar que mesmo isto varia conforme região, identificando assim a existência de várias gramáticas no PB, conforme será demonstrado no final desta seção.

Analisando as diferenças existentes entre as estruturas pronominais de terceira pessoa, comparativamente ao que ocorre no espanhol peninsular, com as forma $\mathrm{el} / \mathrm{le}$, a autora observa que há uma significativa diferença motivada pelo fato de que, no espanhol (assim como no português europeu) o clítico faz parte das estruturas ocorrentes no input de aquisição da 
linguagem, fato não constatável no PB, pois nesta modalidade foi observada a importância da escola no resgate dos clíticos, sobretudo os de terceira pessoa, como será evidenciado no próximo capítulo, a partir das pesquisas de Cordeiro (2004) e Kato (2001), no que se refere às diferenças entre aquisição da linguagem e letramento.

Ramos (op. cit.) expõe sua tese principal a partir da fundamentação proposta nas idéias de Raposo (1999), sobre os determinantes, e as idéias de Chomsky (1995), sobre a noção de economia, estabelecendo que o clítico "lhe" é uma forma polivalente e faz referência tanto ao caso dativo quanto ao acusativo, e, assim, estabelece que não é correto afirmar que o clítico acusativo "o" esteja deixando de figurar no sistema, no que concerne ao preenchimento do objeto direto (contrariando a hipótese de Duarte - op.cit.- sobre a queda do clítico acusativo no preenchimento da posição de objeto direto). Ramos defende que a hipótese da substituição de sistemas (de casual para referencial), pois o clítico passa a se comportar como um determinante (de modo semelhante aos artigos). Nesta perspectiva, a autora adota a perspectiva de Raposo (op. cit.), de que ambos os pronomes "ele" e "lhe" são determinantes complexos, ou seja, determinantes com um nome incorporado no próprio determinante puro, e isto justificaria o fato de estas estruturas não ocorrerem junto a nomes ou artigos, além de possuir grandes semelhanças com os clíticos, no que se refere a sua natureza semântica e sintática, pois ambos são elementos referenciais e específicos. Deste modo, percebemos a natureza co-referencial dos clíticos e a semelhança formal existente entre clíticos e determinantes, pois são elementos referenciais específicos, além de, historicamente, os clíticos de terceira pessoa e os determinantes, nas línguas românicas em geral, serem formas procedentes dos demonstrativos acusativos latinos illum, illam, illud.

Com relação à distribuição das formas "ele" e "lhe", em testes aplicados para verificação deste fenômeno, a autora constatou que há preferência pelo preenchimento do objeto direto com a forma "ele", defendida por Câmara Junior (2004) como sendo uma forma 
sintática invariável, que pode assumir o caso acusativo. Quando o clítico "lhe" é utilizado, constata a autora, a partir das idéias de Kato (1994), percebemos o fenômeno da próclise generalizada, uma vez que nos registros informais o clítico é preferivelmente deslocado à esquerda (conforme Raposo estabelece para o processo de pronominalização). Este fato, assim como sua relevância para este estudo, será melhor explorado no capítulo referente às questões de aquisição e letramento.

Em Uriagereka (1995) encontramos uma importante definição dos clíticos como determinantes: fundamentando-se em questões de gramática histórica, defende que somente os clíticos de terceira pessoa funcionam como determinante, por sua origem atrelada aos demonstrativos latinos, o que releva-lhes a classificação de determinantes fracos, pois se opõem aos pronomes fortes, de primeira e segunda pessoa, de traço indiscutivelmente [+humano], enquanto o de terceira pessoa pode transitar entre os traços [+humano] e [humano] sincronicamente (uma vez que estas estruturas, no latim, eram identificadas apenas para referência [-humano]).

Ramos (op. cit.) recupera o ponto de vista sobre os clíticos, já defendido por inúmeros pesquisadores, que diz respeito ao estatuto atual do clítico no PB. O falante é consciente de que no interior de sua língua convivem várias gramáticas e que os clíticos, sobretudo os acusativos de terceira pessoa são resgatados na escola, e por ela sobrevivem, pois não são mais adquiridos no input.

Neste sentido, Kato $(1993,1994)$ traz uma importante consideração de cunho histórico e fonológico, para explicar uma possível "erosão" do sistema de clíticos, sobretudo no que se refere ao acusativo "o": a mudança de ênclise para próclise, que originaria um vocábulo fonético iniciado por vogal não acentuada, facilitando, assim, a existência de uma substituição crescente deste pelo clítico nulo, que recebe, na maioria dos casos, o traço [- 
animado]. Isto também vem a reforçar a hipótese de que o sistema pronominal do PB está se tornando mais referencial do que casual.

Outra explicação para a queda do acusativo "o" do sistema pronominal do PB pode ser encontrada em Nunes (1993) que aborda o aspecto fonológico, complementando a explicação de Kato (op. cit.) neste contexto. Consiste na idéia de que, a partir da mudança na direção de cliticização (ocorrida no séc. XIX) ficaria impossibilitado o onset (fonema inicial) da sílaba do clítico, tornando-o obsoleto no $\mathrm{PB}$, entrando em queda na preferência dos falantes.

Com base nestas hipóteses, a situação do clítico dativo "lhe" torna-se a seguinte: Este clítico alarga seu domínio e entra em competição com o "te" acusativo nas variedades do PB que não usam mais o pronome "tu", e com o clítico "o" nas variedades que ainda mantém oposição "tu-você", mantendo ainda seu traço [+humano].

Mesmo com estas mudanças, substituições e alargamento de domínios, o clítico "o" não sofreu alterações na sua caracterização lexical, atingindo mais intensamente o paradigma de terceira pessoa, por exemplo, com a introdução da forma "você": na variedade em que esta forma é vigente e freqüente, o clítico "lhe" compete com a forma "te", e nas variedades que mantém a oposição entre "tu" e "você", a referência direta ao interlocutor em uma situação formal, favoreceu a especialização do "lhe" em função acusativa, fato este favorecido também pelo traço do referente [+humano], conforme o quadro que será mostrado adiante.

Tudo o que foi exposto até aqui sobre a tese de Ramos nos permite aventar algumas suposições sobre o sistema pronominal do PB, mais particularmente no que se refere à terceira pessoa do PB: o falante dispõe das formas "ele", "lhe" e "o" (sendo somente as duas últimas utilizadas na referência ao interlocutor) em concorrência direta.

Considerando que os traços [humano] e [animado] são em grande parte responsáveis pela escolha do falante, e esta escolha não ser, de modo algum uniforme, sobretudo quando 
nos atentamos para a referência ao interlocutor, percebemos que o clítico "lhe" não possui um estatuto único no PB. Unindo a relevância dos traços supracitados, aliados ao julgamento do falante, em relações sociais formais e informais (de respeito, cortesia e intimidade), chegamos às definições de Ramos, de que há no mapeamento regional/lingüístico do $\mathrm{PB}$, ao menos três gramáticas, distribuídas da seguinte forma ${ }^{2}$ :

\section{(1) Eixo Rio-São Paulo:}

- "você" como forma de tratamento generalizado;

• "lhe" em função canônica dativa;

• "te" em uso co-ocorrente com "você" na informalidade;

(2) Região Nordeste:

- "você" como forma de tratamento generalizado

- "lhe" em função acusativa ou dativa (em substituição do "te" nestas duas funções casuais);

\section{(3) Região Norte e estado do Maranhão:}

• "tu" e "você" em uso informal (cortesia, informalidade);

• "lhe" como acusativo de "você", "senhor" e "senhora", também em referência ao interlocutor;

- "lhe" em função dativa;

• "te" acompanhando o usos do "tu".

Resumindo as idéias tratadas nesta seção, a autora parte do pressuposto de Chomsky (op. cit.) de que a variação lingüística incide sobre as categorias funcionais. Se os pronomes

\footnotetext{
2 No entanto, é interessante observar que esta classificação não dá conta de explicar, no caso da primeira gramática, o uso de "tu" em oposição a "você" nas regiões litorâneas dos estados mencionados.
} 
são determinantes, logo são categorias funcionais e assim, revelam características de processos de mudança lingüística terminada ou em curso. Nesta perspectiva, a autora procura demonstrar que houve perda do traço de caso [+intrínseco] dos clíticos, fazendo com que o sistema de casos, para estas estruturas, seja substituído pelo sistema referencial, assim os traços referenciais (semânticos) passam a ter grande relevância na determinação da função assumida pelo clítico em situação de uso. 


\section{METODOLOGIA E PRESSUPOSTOS TEÓRICOS}

Conforme evidenciado por Duarte (1989), a utilização do método variacionista estabelecido por Labov $(1972,1982)$ mostra que a variação lingüística não se constitui em um fato ou um conjunto de fenômenos aleatórios, podendo ser explicada por regras categoriais e variáveis, estabelecendo-se um tratamento estatístico por meio da quantificação dos dados configurados como variáveis em um sistema lingüístico específico. Deste modo, nesta pesquisa, esta metodologia será aplicada sobre fatores conduzidos ao nosso objetivo, fatores estes de natureza lingüística, extra-lingüística e, quando gerarem resultados pertinentes, fatores obtidos pela combinação de ambos.

Selecionamos ocorrências de quinta a oitava séries, respectivamente, para análise, de modo que tivéssemos um parâmetro inicial de comparação e, assim, pudéssemos perceber as diferenças relevantes para a realização da posição de objeto direto em relação às hipóteses levantadas até aqui. A seguir, procuramos detalhar um pouco mais os elementos pertinentes a esta análise.

\subsection{Preparação do Corpus}

A análise que se propõe nesta pesquisa busca verificar como o indivíduo inserido no processo de escolarização preenche a posição de objeto de verbos em contextos de formalidade (distância) e informalidade (intimidade), e, diante disto, procuramos estabelecer um corpus que oportunizasse esta análise. Para isto, elaboramos um teste de produção nas duas modalidades discursivas, formal e informal. Estes testes partem de uma atividade proposta aos alunos dos segmentos de Ensino Fundamental II em que é pedida a produção de 
uma carta a partir de um tema e contexto específico, provocando o uso de determinadas estruturas em que poderiam ser observadas as diferentes realizações do objeto direto dos verbos.

Esta análise gerou um total de 1.524 ocorrências de realização do objeto direto na referência ao interlocutor ( $2^{\mathrm{a}}$ pessoa do discurso), distribuídas entre a modalidade formal (595 ocorrências) e informal (929 ocorrências).

\subsubsection{Teste de Produção: Registro Formal}

Este teste busca verificar a produção do objeto direto em uma situação formal de interlocução. Reproduzimos abaixo a proposta de atividade levada aos alunos.

\section{VOCÊ PODE ESCREVER UMA CARTA A UM POLÍTICO?}

\section{CARTA 1 - imagine a seguinte situação:}

Você é o principal representante da Associação do Bairro. Você soube que o Secretário Estadual da Saúde vai participar de um evento no seu bairro.

Você, como representante dos moradores, convidará então o secretário para uma reunião informal na Associação.

O seu comunicado não precisa ser extenso, mas deve mencionar o seguinte:

1. Você ouviu o secretário falar da importância de estar perto da população para conhecer os seus problemas;

2. Por isso, você gostaria de convidar o secretário para participar de um encontro na próxima quarta-feira;

3. Será uma honra para você ter o secretário na sede da associação e conhecer o secretário pessoalmente; 
4. Esta será uma boa oportunidade para encontrar o secretário e discutir sobre a necessidade de um hospital público no bairro;

5. Vocês esperam que o deputado possa estar presente e receberão o secretário com um café da manhã a partir das $10 \mathrm{~h}$.

Atenção: Lembre-se de redigir a carta em $1^{\mathrm{a}}$ pessoa e de se dirigir diretamente ao secretário.

\subsubsection{Teste de Produção: Registro Informal}

Para a modalidade informal do discurso, buscamos elaborar uma situação em que o aluno do Ensino Fundamental se sentisse à vontade para referir-se à $2^{\mathrm{a}}$ pessoa do discurso, com o objetivo de verificar se os mesmos resultados obtidos neste sentido para a modalidade formal verificam-se também na modalidade informal. Abaixo reproduzimos o teste aplicado.

\section{VOCÊ PODE ESCREVER UMA CARTA A UMA GAROTA?}

\section{CARTA 2 - Imagine a seguinte situação}

Um rapaz chamado Antônio estava no clube, e se interessou por uma menina que se divertia com algumas amigas. Ele descobriu que a menina se chamava Maria e que estudava na mesma escola que ele.

Como Antônio é muito tímido, resolveu escrever uma carta e entregar para ela no dia seguinte. Ele tentou escrever, mas a carta ficou muito confusa, assim ele pediu a você que escrevesse a carta para Maria, dizendo tudo que ele gostaria de dizer. Tente organizar a carta de Antônio para Maria, que deve mencionar o seguinte:

1. João viu Maria ontem no clube;

2. João achou Maria muito simpática;

3. Ele quer saber se pode encontrar Maria; 
4. Antônio acha que foi amor à primeira vista. Ele sente que já ama Maria sem nunca ter conversado com ela;

5. Antônio quer encontrar Maria amanhã às dezesseis horas no bar do clube;

6. Ele vai esperar Maria até anoitecer, se for preciso.

Lembre-se de escrever a carta em primeira pessoa. Não se esqueça também de que na carta deve se dirigir diretamente a Maria.

Nestes testes, as cartas serviram de estímulo para que o aluno produzisse, conforme sua percepção, enunciados, preenchendo a posição do objeto de modo a revelar os contrastes relativos à influência da escola na utilização dos clíticos, e quais clíticos seriam utilizados por eles em determinadas situações de interlocução.

\subsection{Local de aplicação dos testes: Colégio Marista Nossa Senhora da Glória}

O Colégio Marista Nossa Senhora da Glória é um colégio católico, mantido e gerido pelos irmãos da congregação Marista, e situa-se próximo ao Largo do Glicério, que é uma área limitada pelo viaduto do Glicério (que dá acesso à Radial Leste), pelos prédios de uma igreja evangélica e de órgãos governamentais, um albergue e um conjunto habitacional, e está situado entre os bairros da liberdade, Cambuci e Centro.

Nesta região, a organização de edifícios institucionais e os viadutos recortam esse plano, impedindo a integração do fluxo urbano residencial convencional. Toda a região foi urbanisticamente desconfigurada, o que afastou investimentos imobiliários e atraiu uma grande massa de população carente e sem-teto. Nesta Região encontra-se a maior concentração de entidades assistencialistas (albergues, centros comunitários, igrejas) da cidade. Assim, percebemos que é um lugar onde grandes investimentos em circulação 
resultaram num espaço onde a cidade formal não chega. A população que está na área é composta basicamente por alberguistas e pelos moradores de rua.

O largo situa-se nos limites de diversos planos de intervenções localizadas de revitalização da área central, como a Operação Urbana Centro, sem que essas iniciativas tenham conseguido reorientar a ocupação da região. Ele também se localiza logo abaixo do perímetro previsto para a área de implantação do projeto SP Tower. Nesta região se sobrepõem a construção de grandes vias expressas, com a conseqüente falta de investimento e ocupação informal. Isolada pelos viadutos, não pode também ser integrada aos recentes projetos das subprefeituras regionais de desenvolvimento em grande escala da Zona Leste.

É neste cenário que se encontra o Colégio Marista Nossa Senhora da Glória, um colégio católico que tem como público predominante, a classe média residente na região central, Ipiranga, Liberdade e Aclimação. Em sua maioria, os alunos são filhos de comerciantes da região. Nem todos são católicos e o colégio é geralmente escolhido pela qualidade de ensino e valor da mensalidade, pois é um dos melhores da região e não tem valores de mensalidade muito altos. Percebe-se que, quando os pais tem melhores condições financeiras e pretendem que os filhos estudem em um colégio melhor, também de uma rede católica, dão preferência aos colégios da Vila Mariana (tais como o Marista Arquidiocesano, Madre Cabrini e o Rainha da Paz), pois é a região imediatamente próxima. O colégio existe na região há pouco mais de cem anos, portanto é ao mesmo tempo uma instituição tradicional e conservadora, em sua estruturação e um colégio desprestigiado por ser considerado uma instituição que não se adequou aos novos tempos, além de estar situado em uma região que demanda novos investimentos para urbanização e crescimento. 


\subsection{Fatores para análise}

Para este estudo, a partir da necessidade de um corpus elaborado, que revelasse os fenômenos que pretendemos analisar, foram elencados alguns fatores de natureza lingüística e extralingüística. Estes fatores foram combinados na amostra analisada, direcionados às hipóteses aqui levantadas, buscando como objetivo principal observar em que circunstâncias ocorrem as diferentes realizações do objeto direto, e qual a influência de cada tipo de fator neste processo.

a) Preenchimento da posição de objeto: Este fator objetiva analisar a realização do objeto direto. Descartamos os objetos sentenciais por não terem relevância à pesquisa empreendida aqui. A seguir, observamos as variantes possíveis e alguns exemplos encontrados no corpus analisado.São eles:

i) Pronome tônico: “... e ouvimos o senhor dizendo que seria uma oportunidade...” (5 $5^{\mathrm{a}}$ série);

ii) Clítico: 259- “Assim, gostaríamos de te convidar para ...” (8 ${ }^{\mathrm{a}}$ série);

iii) Sintagma nominal; “ “...convidamos o mais novo Secretário de Saúde de São Paulo para...” (5 série);

iv) Objeto nulo: “Nós $\varnothing$ receberemos com um saboroso café... (8 $8^{\mathrm{a}}$ série).

b) Tipo de clítico: em relação ao clítico, pretendemos observar se o objeto direto, em referência ao interlocutor, é preenchido por uma destas três formas, independentemente se o registro de língua refere-se ao discurso formal ou informal:

i) te: “Quando eu te vi pela primeira vez...” (5 série);

ii) lhe: “...estarei lhe mandando um bilhete ...” ( $8^{\mathrm{a}}$ série); 
iii) o/a (e alomorfes): “...não estou forçando-a a me encontrar... ( $8^{\mathrm{a}}$ série).

c) Estrutura verbal: Este fator busca combinar o tipo de realização observada para o objeto direto com o tipo de estrutura verbal, para verificar se há alguma tendência de privilegiar o maior uso de uma estrutura em detrimento de outra. Assim temos:

i) verbo simples: “Receberemos você com um ótimo café ...” ( $8^{\mathrm{a}}$ série);

ii) locução verbal: “...estarei lhe mandando um bilhete ...” ( $8^{\mathrm{a}}$ série).

d) Posição do objeto na sentença: Este fator tem a função de verificar se há preferência por uma determinada posição para o clítico em relação ao verso. Deste modo temos dois fatores (i e ii) para estruturas oracionais com verbos simples e três fatores (iii, iv e v) para estruturas oracionais que utilizem locuções verbais (ou grupos verbais):

i) antes do verbo: -“ ...e teria o enorme prazer de lhe receber ...” ( $8^{\mathrm{a}}$ série);

ii) depois do verbo; - “...por isso decidimos convida-lo ...” ( $8^{\mathrm{a}}$ série);

iii) V1 + V2 + objeto: “...por isso decidimos convida-lo ...” (8 $8^{\mathrm{a}}$ série);

iv) V1 + objeto + V2: "Estamos te esperando às ...” ( $5^{\mathrm{a}}$ série);

v) objeto + V1 + V2: -“ ... lhe estarei mandando um bilhete ...” (8 ${ }^{\mathrm{a}}$ série).

e) Forma nominal de V2: Independentemente do tipo de estrutura oracional, este fator visa verificar a forma nominal em que se encontra V2 da estrutura verbal [V1 auxiliar + V2 (segundo verbo)]. As possibilidades são três, a saber:

i) Infinitivo: “...Gostaria de lhe convidar para... (6 $6^{\mathrm{a}}$ série);

ii) Gerundio: “Estarei lhe esperando...” (5ª́rie); 
iii- Particípio: “Jurava já ter te visto ...” ( $8^{\mathrm{a}}$ série).

f) Modalidade discursiva - tipo de registro: Este é um fator determinante para este estudo, pois verificaremos quais as diferenças encontradas na alternância entre o discurso formal e informal, quais as diferenças entre a realização do objeto direto em um registro e outro, e, contrastando com as idéias que embasam esta pesquisa, qual a relevância que isto pode ter em relação às hipóteses aqui levantadas.

g) Série escolar: O corpus foi elaborado em todas as séries dos segmentos de Ensino Fundamental II, com a finalidade de observar se há, ao longo das séries escolares, alteração na realização do objeto direto em relação ao interlocutor e se, portanto, a escola dá ao aluno os instrumentos gramaticais que diferenciem a modalidade informal da formal no tratamento do interlocutor.

\subsection{Aquisição da linguagem}

A aquisição da linguagem é um problema complexo, que não encontra definições e explicações simples. Conforme estabelecido por Chomsky em inúmeros trabalhos, a linguagem é um "sistema de conhecimentos interiorizado na mente humana”, e nesta perspectiva, a aquisição da linguagem encontra a seguinte questão, reproduzida de Raposo (1992):

"Como é que o sistema de conhecimentos da linguagem se desenvolve na mente do falante? Que tipo de conhecimento é necessário pressupor que a criança traz a priori para o processo de aquisição de uma língua particular para explicar o desenvolvimento dessa língua na sua mente?”

Tendo em vista esta questão, grande parte da exposição a ser apresentada aqui discute a noção de parametrização com o intuito de observar com o que exatamente a criança conta 
no processo de aquisição (daí a necessidade de discutir também as visões diferenciadas acerca das hipóteses de aprendizagem existentes e, sobretudo, relevantes).

Esta teoria leva em consideração pressupostos tais como (i) Fundamentar-se nos sistemas de performance; (ii) Considerar que qualquer elemento relevante para adequação explicativa e descritiva deva ser conceitualmente motivado ${ }^{3}$; é estabelecida então a seguinte questão: Haveria alguma propriedade essencial na faculdade da linguagem para além da marcação paramétrica na Gramática Universal (doravante GU) que seja atuante no processo de aquisição? Podemos deduzir que esta questão esteja voltada estritamente para a Faculdade da Linguagem, e se existiria algum elemento fundamental ligado à aquisição da linguagem que não estivesse imediatamente ligado à marcação paramétrica.

Quando surge o modelo de Regência e Ligação (doravante R\& L), este tinha como objetivo descrever as línguas particulares a partir dos processos sintáticos que estas sofriam, o que não dava conta de outras questões sobre a aquisição da linguagem. Somente a partir da teoria de Princípios e Parâmetros (doravante P\&P) é possível perceber uma tentativa plausível de explicação do conhecimento lingüístico que surge na mente do falante, juntamente à introdução das idéias escolásticas sobre o universalismo (GU), fundamentadas por Chomsky principalmente nos pressupostos contidos na Gramática de Port-Royal entre outros ${ }^{4}$. Neste momento, começa-se a alcançar alguma adequação descritiva das línguas particulares juntamente à explicação do conhecimento lingüístico contido na mente do falante, tendo como objetivo, acima de tudo, caracterizar o estágio inicial $\left(\mathrm{S}_{\mathrm{o}}\right)$ da língua, quando começa a ser adquirida pela criança, até seu estado estável ( $\left.\mathrm{S}_{\mathrm{s}}\right)$.

Em outras palavras, temos como conseqüência disto, o fato de que, quando chega a noção de GU, o modelo deixa de descrever somente a regularidade entre as diferentes línguas

\footnotetext{
3 Ser conceitualmente motivado, segundo a autora, significa possuir relação com os componentes de performance e as restrições que estas ditam às interfaces.

${ }^{4}$ A discussão relativa ao Universalismo na linguagem é feita com bastante propriedade por Chomsky, 1972 (Lingüística Cartesiana), não cabendo aqui maiores comentários acerca do assunto.
} 
e passa a traduzir, também, a organização da mente humana. Nesta perspectiva, a aquisição da linguagem começa a ser explicada pela formatação da Faculdade da Linguagem a partir da fixação de valores paramétricos: uma vez fixado um valor para todos os parâmetros, a criança alcançaria a Língua-I (interna, individual e intencional).

Um parâmetro é definido como um conjunto de possibilidades pré-determinadas, variável de língua para língua. Este conceito nos permite observar a estrutura organizacional da mente do falante, partindo dos princípios universais (daí, genéticos), e não mais somente a regularidade entre as línguas. Assim, quando no estágio da aquisição, a criança atingiria um nível estável Ss, uma vez tendo preenchido todos os parâmetros da língua a qual está exposta. Temos, deste modo, em P\&P, princípios fixos, invariáveis, universais a todas as línguas, e parâmetros variáveis de língua para língua, o que faz presente a seguinte questão: como princípios invariáveis podem admitir parâmetros variáveis em uma língua?

Ampliando um pouco mais a questão dos parâmetros neste exemplo, chegamos à proposta de Lightfoot, 1989 que infere que o acionamento paramétrico se dá essencialmente com dados simples, o que não se confirma em alguns casos, fazendo com que tenha que ampliar o limite dado ao acionamento paramétrico, incorporando a noção de domínio de Regência. Isto demonstra que o caráter descritivo do modelo teórico tem avançado consideravelmente, reforçando a noção de volatibilidade dos parâmetros em detrimento da inviolabilidade dos princípios. Em aquisição, isto significa dizer que o acionamento paramétrico se dá logo na aquisição do léxico, pois possui tais características distributivas ${ }^{5}$.

Em alguns casos, como os princípios de ligação, foi constatado por alguns pesquisadores que algumas línguas os violam (Lopes 1999, apud Sportiche, 1986; Wexler \& Manzini, 1987,), reforçando a necessidade de dissociar-se princípios de parâmetros. Para

\footnotetext{
${ }^{5}$ Lopes (1999) ilustra esta afirmação a partir da marcação de caso, que se dá ou de forma canônica ou por ECM (Exceptional Case Marking), que ocorre quando um núcleo atribui caso a um complemento de outro núcleo. Estas características são fundamentadas nas propriedades lexicais.
} 
esclarecimento deste ponto, foi dado como exemplo a anáfora jibun, do Japonês. O que se conhece sobre as anáforas, nas perspectivas apresentadas até aqui, nos levaria a crer que, então, dada a ocorrência do princípio de ligação em algumas línguas, intuitivamente poderíamos pensar em duas hipóteses, a saber:

(i) Ou o princípio em questão é, na verdade, um parâmetro mal interpretado (grifo meu);

(ii) Ou necessita-se de mais algumas informações para definir melhor o princípio enquanto tal.

Na tentativa de dar conta deste problema, Wexler \& Manzini (op. cit.) tentarão aliar o conceito de princípio à aquisição da linguagem, partindo do pressuposto de que "cada escolha que a criança faz é motivada por um princípio (GU)”. Assim, surge a proposta do Subconjunto, em que os valores paramétricos se distribuiriam em camadas hierarquicamente ordenadas. Deste modo, se um parâmetro não pudesse ser acionado, um outro parâmetro consecutivo daria conta do caso. Porém, para que um parâmetro não afete a marcação de outro, é necessário postular-se que haja independência entre eles (Princípio da Independência, que deve atuar junto ao subconjunto). Deduz-se, então, que os parâmetros estão intimamente associados aos itens lexicais particulares a uma determinada língua.

Kato, (1999), no entanto, se contrapõe a esta noção por considerar que isto dá a entender uma variação paramétrica infinita, o que impossibilitaria a uma criança definir o espaço paramétrico de sua gramática em aquisição. 


\section{$2.5 \quad$ Hipóteses sobre a aprendizagem da escrita}

Kato (1999), demonstra a existência de um distância entre a língua falada e a escrita no português europeu e no português brasileiro, revelando que, neste último, a distância é de tal ordem que pode-se considerar o processo de letramento como um processo que, de certo modo, cria a aprendizagem de estruturas que não mais são adquirida na fala. Isto faria com que o processo de letramento promovido pela escola poderia ter a natureza da aprendizagem de uma segunda língua, no PB, uma vez que, ao contrário do PE, há diferenças fundamentais entre a fala e a escrita e, consequentemente, entre a aquisição da linguagem e o sistema adquirido pelo letramento. Um bom exemplo disto, é o uso de estruturas clíticas: como já demonstrado, a escola é responsável pelo municiamento do indivíduo, falante nativo do PB, a utiliza-los, pois denota-se que eles foram perdidos há muito da língua falada. Com relação a isto, Kato (op. cit.) levanta as seguintes hipótese:

“a) dado o caráter conservador das normas da escrita, o processo de letramento recupera o conhecimento gramatical de um indivíduo de alguma época passada do português brasileiro ou; b) dados os convênios culturais com Portugal, que privilegia a unidade lingüística entre os países, esse saber é pautado no conhecimento lingüístico do falante português, e c) (...) esse conhecimento se define como algo distinto dos outros dois.”

A autora buscará defender a hipótese de que há algo distinto das duas primeiras hipóteses que explique este conhecimento, embasando-se na teoria de Princípios \& Paramentos, conforme estabelecida por Chomsky (1986), pois na aquisição de uma segunda língua (L2), o acesso a uma gramática universal é indireto, via a primeira gramática - a da língua falada. Nesta linha, há a hipótese de que a gramática da L1 (língua materna) contém “uma periferia marcada onde valores paramétricos opostos ao da gramática nuclear podem estar presentes, com caráter marcado, recessivo, valores esses que podem assumir um valor 
competitivo, durante o letramento, em relação aos valores que se encontram definidos na gramática nuclear”.

Em Cordeiro (2004), percebemos a concordância com Kato (op. cit.) no que se refere à consideração do clítico como morfologia estilística, pois a escola não recupera as estruturas clíticas na fala, mas somente na escrita, pois no estudo que a autora faz sobre o clítico acusativo de $3^{\text {a }}$ pessoa, em especial da forma “o”, foi possível verificar que a escola tem um papel fundamental na recuperação, pois muitas das ocorrências em que se constata o uso do clítico na escrita, mesmo que não esteja em conformidade com o que prescreve o ensino formal (tais como usos e colocações não previstas pelas gramáticas normativas), não se verifica na modalidade falada da língua.

\subsection{Hipercorreção e Erro}

Na dissertação de Silva (2007), em que é estudada a aprendizagem dos pronomes relativos, assim como o contexto em que estes ocorrem na língua escrita, observamos uma interessante diferenciação para os desvios gramaticais e as produções de sentenças (ou de expressões internas a estas) não-usuais na língua portuguesa, que certamente podem orientar a análise a ser empreendida em relação à realização e posição dos clíticos no presente estudo.

Consistem na diferenciação de tais desvios em hipercorreção ou erro, propriamente dito. A hipercorreção (ou ultracorreção) poderia ser definida em um desvio ocasionado pela preocupação em produzir um enunciado (na escrita ou na fala) correto, definido como uma forma de bom uso da língua, de modo a fugir das variantes lingüísticas consideradas pouco prestigiadas para uma situação formal de interlocução. Isto ocorre, sobretudo, quando o indivíduo é exposto à norma gramatical, prescrita pela escola. Neste contexto, o falante ainda 
não domina a norma gramatical a que foi exposto nas aulas de gramática, mas julga estas formas adequadas, o que entra em conflito com a gramática de que já faz uso, adquirida em tenra idade, culminando, por vezes, na correção daquilo que estava correto. Assim, conforme a autora, hipercorreção pode ser considerada como uma “deformação do uso lingüístico correto”.

A noção de erro, por contraste, passa a ser então a simples produção de sentenças ou expressões gramaticais, mal formadas, que não seriam aceitas como usuais em nenhuma variedade lingüística, seja na modalidade formal ou informal, seja na língua falada ou escrita, ou seja, “uma frase é gramatical se ela pertence a uma determinada língua natural, e a gramatical se sua construção não faz parte da estrutura aceita e legitimada por esta língua” (Silva 2007: 160).

\subsection{Especialização e Substituição de Formas}

Conforme as definições encontradas em Negrão \& Muller (1996), com relação ao estudo das categorias vazias e lexicais na posição de sujeito, e a distribuição das formas possessivas de $3^{\text {a }}$ pessoa (“seu” e “dele”) e Pereira (2005), em seu estudo acerca dos usos de “esse” e "este” no português brasileiro e o europeu, quando tratamos da questão da mudança lingüística, pode ocorrer o desaparecimento de uma determinada estrutura gramatical ou esta simplesmente pode passar a seu utilizada em um outro contexto lingüístico em que anteriormente não figurava.

Neste panorama, abre-se a possibilidade da existência de dois processos. Um destes processos é o de substituição, que é utilizado por Pereira (op. cit.) para justificar as mudanças no PB com relação ao uso dos demonstrativos “este” e “esse”, e o outro é o processo de especialização, utilizado no estudo de Negrão \& Muller (op. cit), para justificar a coexistência 
das formas pronominais (“seu” e “dele”, por exemplo, para a noção de posse em referência à $3^{\mathrm{a}}$ pessoa) no sistema gramatical do $\mathrm{PB}$, sem que tenha havido o desaparecimento de uma em detrimento da outra. Dentro de um mesmo sistema cada forma assume uma função.

Para Pereira, ambos os conceitos de substituição e especialização de formas são processos opostos e somente podem ser verificados quando há a estabilização de um dado sistema gramatical em análise, após iniciado um processo de mudança na língua.

Assim, caracterizamos a substituição de formas como um processo pelo qual um termo passa a ser utilizado, ao longo do tempo, no lugar de outro, até que este último desapareça por completo. Como um bom exemplo temos a pesquisa de Pereira, já mencionada anteriormente, sobre os pronomes demonstrativos “este” e “esse” do PB, em que afirma que a forma "esse” é um caso de substituição em relação à forma “este”, pois o primeiro vem agindo e se estabilizando no contexto de uso do segundo de modo crescente, conforme a análise empreendida pelo autor sobre corpus de textos escritos formado para este fim.

Já especialização de formas é considerada, como conseqüência, um processo pelo qual uma forma que antes era utilizada em um determinado contexto passa a ser utilizada em outro contexto, sem que a forma anterior utilizada e que caiu em freqüência de uso desapareça. Em outras palavras, uma estrutura gramatical deixa de ser usada com a sua função canônica e, aos poucos, encontra uma nova função dentro do sistema.

O estudo de Pereira observou um caso de substituição de formas em um contexto em que uma pesquisa anterior atestou a ocorrência de um caso de especialização, o que indica que a especialização de formas possa ser uma etapa intermediária à substituição, ou seja, é possível que no percurso travado, rumo a uma substituição, parcialmente observe-se um contexto de convivência entre formas para usos distintos, que pode diferir do uso originalmente conferido por essas formas. Isto, no entanto, é o indicativo da possibilidade de se cometer um equívoco conferir o estatuto de especialização ou substituição de uma forma 
em relação a outra em um contexto de mudanças não estabilizadas, o que indica que esta deveria ser a primeira questão a ser considerada para que haja, neste sentido, uma análise consistente.

Assim, é importante notar que, para que se caracterize uma especialização de formas é necessário que haja uma estabilização no sistema, que possa ser comprovada por meio de dados, uma vez que somente a observação do comportamento dos elementos integrantes a um determinado sistema lingüístico em um determinado período de tempo pode atestar ou não a estabilização das formas em uma gramática, mesmo que haja um contexto de resistência ${ }^{6}$.

\footnotetext{
${ }^{6} \mathrm{O}$ contexto de resistência pode levar a uma presunção de especialização de formas precipitada, pois pode acontecer o caso de uma forma que está em processo de substituição por outra manter durante um certo período de tempo certa produtividade, até que caia em desuso completamente. O problema consiste no fato de não ser possível precisar o tempo que leva para uma forma substituir outra em um dado sistema lingüístico, pois neste caso deve ser levados em consideração fatores extralingǘsticos.
} 


\section{$3 \quad$ Análise descritiva dos dados}

Ao todo, foram computadas 1.524 ocorrências de objeto direto em referência ao interlocutor nas quatro séries do Ensino Fundamental, sendo 595 ocorrências (cerca de 40\% do total) na modalidade discursiva formal e 929 ocorrências (cerca de $60 \%$ do total) na modalidade informal.

A diferença percentual entre as duas modalidades poderia ser um indicativo de que, na modalidade discursiva informal, o aluno tem maior liberdade no uso da língua, e uma vez que a informalidade produz um contexto semelhante ao da língua oral, o aluno sentiria maior segurança (ou maior liberdade) na escolha da forma a preencher a posição de objeto direto, o que não ocorre na modalidade formal, pois neste contexto o aluno do Ensino Fundamental certamente tentará se valer do sistema e da norma gramatical aprendidas na escola, desde o início do processo de letramento, gerando um contexto não tão livre, no que se refere ao uso corrente a língua. Deste modo, chamamos então a atenção para a relevância da consideração dos dados dentre estas diferenças de contexto, pois este contraste tem como intenção demonstrar a influência do contexto e situação na realização e preenchimento da posição de objeto direto.

Este capítulo está dividido em duas partes (cada uma relativa a uma modalidade), em que analisaremos a realização do objeto direto, enfatizando o preenchimento por pronomes clíticos, procurando observar a maior ou menor relevância dos fatores lingüísticos, sociais e discursivos na análise ora proposta. Ao final de cada sub-seção elaboramos uma reflexão sobre os dados descritos, contemplando um posterior contraste entre resultados obtidos, com o objetivo de confirmar ou descartar as hipóteses levantadas anteriormente, indicando assim novos rumos para o estudo do sistema gramatical do PB atual. 


\subsection{Parte I: Modalidade Formal}

Nesta modalidade, o teste aplicado simulou uma situação em que os alunos se sentiriam impelidos a utilizar-se das normas e convenções socialmente aceitas e orientadas para uma situação formal de interlocução, conforme o que a escola ensina. As próximas seções demonstrarão a regularidade do uso dos constituintes na posição de complemento e os contrastes observáveis entre o input e o letramento, ou seja, a língua adquirida em tenra idade e a influência da escola na escolha das estruturas lingüísticas orientadas ao uso.

\subsubsection{Realização do complemento verbal}

Nesta modalidade discursiva, constatamos que o objeto direto em referência ao interlocutor é preenchido dentro de um pequeno número de opções: pronome (clítico ou tônico), sintagma nominal ou objeto nulo (apagamento), nas séries analisadas do Ensino Fundamental II, conforme demonstrou a tabela abaixo:

Tabela 1: Formas de objeto direto: número de ocorrências e percentual : modalidade formal ${ }^{7}$

\footnotetext{
${ }^{7} \mathrm{Na}$ forma de referência ao interlocutor na modalidade formal, as formas não-clíticas mais utilizadas são as formas "você" e "senhor". Retiramos, do total de ocorrências com pronomes tônicos e sintagmas nominais, os percentuais de uso destas formas de tratamento por série.
}

\begin{tabular}{|l|l|l|l|l|l|}
\hline & $\mathbf{5}^{\mathbf{a}}$ série & $\mathbf{6}^{\mathrm{a}}$ série & $\mathbf{7}^{\mathrm{a}}$ série & $\mathbf{8}^{\mathbf{a}}$ série & Total \\
\hline senhor & $49 / 58,3 \%$ & $52 / 82,5 \%$ & $52 / 82,5 \%$ & $55 / 91,6 \%$ & 208 \\
\hline você & $35 / 41,7 \%$ & $11 / 17,5 \%$ & $5 / 17,5 \%$ & $5 / 8,4 \%$ & 56 \\
\hline total & 84 & 63 & 57 & 60 & 264 \\
\hline
\end{tabular}

Verificamos que o número de ocorrências de "senhor" aumenta bastante na passagem da $5^{\mathrm{a}}$ para a $6^{\mathrm{a}}$ série e continua a aumentar gradativamente ao longo das séries (inversamente proporcional à queda da forma "você"). Isto é um bom indicativo de que aos poucos o aluno toma consciência do uso de uma variante que julga ser de mais formalidade e respeito. Foi observado, também, o uso de outras formas de tratamento, em menor número, 


\begin{tabular}{|l|l|l|c|l|}
\hline Clítico & Pr. Tônico & SN & Objeto nulo & total \\
\hline N. oc. / \% & N. oc. / \% & N. oc. / \% & N. oc. / \% & N. oc. \\
\hline 247 / 41,5 & 54 / 9,1 & $274 / 46,1$ & $20 / 3,3$ & 595 \\
\hline
\end{tabular}

Dentre estas ocorrências, podemos observar os seguintes exemplos de preenchimento da posição de objeto:

a) Clítico: 002 - Seria uma honra te-lo aqui conosco;

428 - Por isso estou lhe convidando.

b) Pronome Tônico: 007 - Ouvi você dizer;

041 - Nós Ouvimos o senhor falar.

c) Sintagma Nominal: 034 - Esperamos o seu comparecimento;

026 - Estamos ansiosos para encontrar o secretário.

d) Objeto Nulo: 154- Assim, receberemos 0 para uma grande festa; 248 - ..e esperamos 0 com prazer.

Os resultados da tabela acima mostram que na modalidade formal há maior incidência de sintagmas nominais $(46,1 \%)$ que quase empata com os clíticos (41,5\%). O pronome tônico é uma forma de realização de objeto direto de baixa produtividade $(9,1 \%)$, assim como o objeto nulo, com o baixo índice percentual de 3,3\%, que juntos somam pouco mais de $10 \%$ do total de ocorrências. Deste modo, observamos que duas são as formas preferenciais de preenchimento do objeto direto na modalidade formal: o clítico e o sintagma nominal.

Estes resultados se contrapõem aos achados de Duarte (1986) para o clítico acusativo de $3^{\mathrm{a}}$ pessoa e demonstram que o fato de o clítico concorrer com o pronome tônico revela que não só a escola é responsável pelo municiamento do aluno no uso das estruturas, como

tais como V. Excia. (5 $5^{\mathrm{a}}$ série -7 ocorrências; $6^{\mathrm{a}}$ série -3 ocorrências; $7^{\mathrm{a}}$ série -2 ocorrências; $8^{\mathrm{a}}$ série -2 ocorrências), Ilmo. ( $7^{\mathrm{a}}$ série -3 ocorrências) e V. Sa (8 ${ }^{\mathrm{a}}$ série -1 ocorrência). 
também legitima estratégias de substituição do mesmo, pois o clítico acusativo é considerado uma variante conservadora enquanto o pronome pleno é considerado, na posição de objeto, uma variante inovadora na língua falada. No entanto, quando consideradas as situações formais de interlocução, é notório que o uso de um pronome não-clítico é ligeiramente estigmatizado devido ao fato de ser associado à fala de pessoas de baixa (ou nenhuma escolarização), pois estudos revelam ${ }^{8}$ que o clítico é aprendido na escola, e pessoas de baixa ou nenhuma escolaridade não fazem uso do clítico na fala.

A seguir, analisamos as formas de realização do objeto direto por série escolar, com a finalidade de observar se a distribuição é a mesma ao longo das séries ou se o uso de clítico, por exemplo, é adquirido ao longo das séries do Ensino Fundamental em detrimento das demais formas, assim como se há influência de alguma série em especial no municiamento e uso de alguma forma clítica em especial em detrimento de outros e, caso isto ocorra, quais motivos estariam levando a isto.

Observemos agora a tabela 2 abaixo, que trata da distribuição do tipo de realização do objeto ao longo das séries escolares:

Tabela 2: Formas de objeto direto X séries escolares: modalidade formal

\begin{tabular}{|l|c|c|c|c|c|}
\hline $\begin{array}{l}\text { Formas OD/ } \\
\text { Série }\end{array}$ & Clítico & Pron. tônico & SN & Objeto nulo & total \\
\hline & N. oc. / \% & N. oc. / \% & N. oc. / \% & N. oc. / \% & N. oc. \\
\hline $\mathbf{5}^{\text {a. série }}$ & $57 / 35,4$ & $33 / 20,5$ & $65 / 40,4$ & $6 / 3,7$ & 161 \\
\hline $\mathbf{6}^{\text {a. série }}$ & $61 / 41,8$ & $11 / 7,6$ & $68 / 46,5$ & $6 / 4,1$ & 146 \\
\hline $\mathbf{7}^{\text {a. série }}$ & $82 / 50,0$ & $5 / 3,0$ & $74 / 45,1$ & $3 / 1,9$ & 164 \\
\hline $\mathbf{8}^{\text {a. série }}$ & $47 / 38,0$ & $5 / 4,0$ & $67 / 54,0$ & $5 / 4,0$ & 124 \\
\hline
\end{tabular}

De todas as formas de realização do objeto direto em face do interlocutor, o clítico é a forma que apresentou maior incidência em todas as séries, com uso mais acentuado na $7^{\text {a }}$

\footnotetext{
${ }^{8}$ Duarte, 1986, Nunes, 1996, Cordeiro, 2004, entre outros.
} 
série, período em que a sintaxe dos pronomes átonos é foco de atenção na escola, criando a consciência da norma padrão.

A menor incidência do uso do pronome tônico ocorre justamente nessa série escolar, o que parece confirmar que o foco dado ao ensino da sintaxe de colocação dos pronomes átonos na escola é uma hipótese plausível para o pico dos clíticos, sugerindo que a aprendizagem da norma culta gramatical ensinaria as regras de substituição para os pronomes plenos, estratégia esta comumente utilizada na fala para preencher a posição de objeto direto por pronomes clíticos. Entretanto, na $8^{\mathrm{a}}$ série, parece haver um retrocesso no uso do clítico, que passa a ter uso pouco inferior aos 50\%, embora o pronome tônico permaneça com índice baixo, correspondente a $4,0 \%$.

No gráfico 1 a seguir podemos observar melhor a proporção relacionada ao preenchimento do objeto em cada série.

Gráfico 1: Formas do objeto direto X série escolar: modalidade formal.

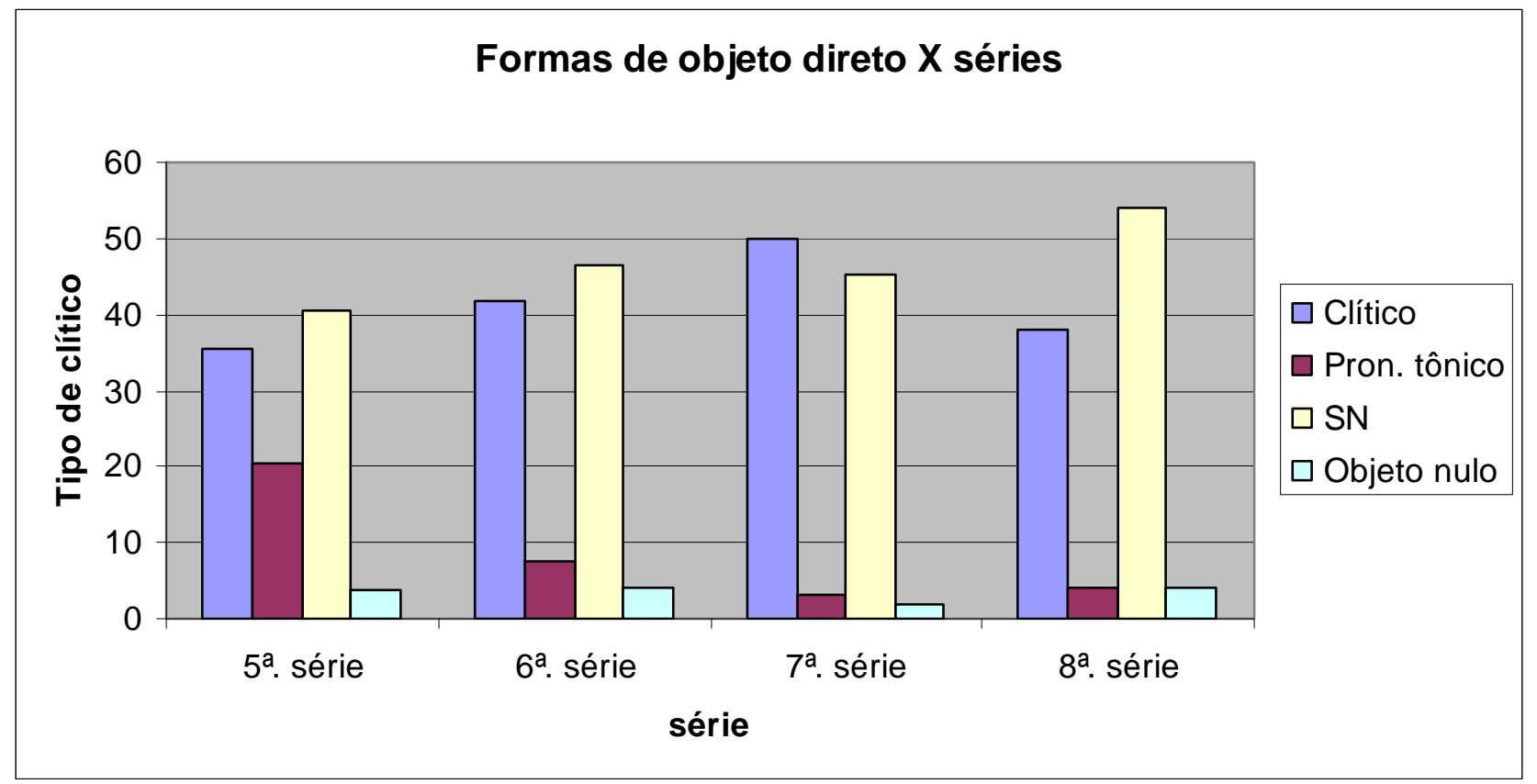

A partir deste momento, vamos restringir a análise aos clíticos, que efetivamente constituem o objeto do presente estudo, com vistas a observar se o tipo de clítico que aparece 
na modalidade formal assemelha-se em proporções aos resultados encontrados na modalidade informal, assim como a posição que estes ocupam em relação à estrutura verbal e, consequentemente à estrutura oracional. Comecemos pela análise da tipologia dos clíticos.

\subsubsection{Tipo de clítico na função de objeto direto em referência ao} interlocutor

Com relação ao tipo de clítico utilizado na referência ao interlocutor, os dados mostram o uso das formas "te”, e “o”, de função acusativa e da forma "lhe”, de função canônica dativa. Uma vez que todos eles são utilizados na mesma função sintática, ou seja, referência à segunda pessoa do discurso, como complementos de verbos transitivos diretos, percebemos que todos se enquadram no caso acusativo na situação de uso em questão. $\mathrm{O}$ clítico “o”, em especial, oferece para este estudo interessantes dados para análise uma vez que cada vez mais tem sido notada e constatada a queda de seu uso na fala, ficando sob responsabilidade da escola mantê-lo vivo no sistema lingüístico a partir da escrita. Pesquisas mostram que a mudança de direção fonológica do clítico que vem ocorrendo desde o século XIX causou o impedimento do licenciamento do onset da silaba da forma clítica “o”, de modo que este somente poderia ser licenciado por outros processos. Assim, as diferentes proporções deste clítico em relação ao uso observado das formas “te” e "Ihe”, nas diferentes modalidades da língua deverão revelar o processo atual em curso do estabelecimento da gramática vigente, em uso no PB.

A tabela a seguir apresenta os dados gerais da tipologia dos clíticos: 
Tabela 3: Tipo de clítico na função de objeto direto em referência ao interlocutor: modalidade formal

\begin{tabular}{|l|l|l|l|}
\hline TE & O & LHE & Total \\
\hline N. de Oc. / \% & N. de Oc. / \% & N. de Oc. / \% & N. de Oc. \\
\hline $56 / 22,7$ & $152 / 61,5$ & $39 / 15,8$ & 247 \\
\hline
\end{tabular}

Dentre os clíticos mencionados, é relevante observar alguns exemplos de sentenças em que estes ocorreram. Buscamos selecionar dois exemplos para cada tipo de clítico:

a) TE: 175 - Estamos te convidando para uma homenagem...;

256 - Te Receberemos com uma festa.

b) O: 234 - Será uma honra recebe-lo;

264- Nós o esperamos amanhã.

c) LHE: 378 - Estou lhe escrevendo esta carta...;

391 - Mas lhe esperamos com muita vontade.

Os dados sugerem o uso preferencial do clítico acusativo “o”, que apresenta alto índice percentual (61,5\%). Este fato contraria nossas expectativas, tendo em vista que vários estudos a respeito desse clítico têm mostrado que seu uso é residual no Português Brasileiro. As formas “te” acusativa e "lhe” dativa apresentam índices bastante próximos, com 22,7\% e 15,8\% respectivamente, o que nos leva a inferir uma competição entre essas duas formas nesta modalidade, em oposição à forma acusativa “o”.

A grande incidência do clítico acusativo “o” nas produções dos alunos nos leva a indagar se a preferência por essa forma pronominal é constante em todas as séries, ou se é adquirida ao longo do processo escolar. Para observar estas questões, iniciaremos pela análise dos tipos de clíticos por série. As 247 ocorrências estão distribuídas na tabela a seguir. 
Tabela 4 - Tipo de clítico por série escolar : modalidade formal

\begin{tabular}{|l|c|c|c|c|}
\hline Clítico / Série & \multicolumn{1}{l|}{ TE } & \multicolumn{1}{l|}{ O } & \multicolumn{1}{l|}{ total } \\
\hline & N. oc. / \% & N. oc. / \% & N. oc. / \% & N. oc. \\
\hline $5^{\text {a }}$ série & $12 / 21,0$ & $24 / 42,1$ & $21 / 36,9$ & 57 \\
\hline $\mathbf{6}^{\text {a }}$ série & $19 / 31,1$ & $34 / 55,7$ & $8 / 13,2$ & 61 \\
\hline $7^{\text {a }}$ série & $20 / 24,4$ & $57 / 69,5$ & $5 / 6,1$ & 82 \\
\hline $\mathbf{8}^{\text {a }}$ série & $5 / 10,6$ & $37 / 78,8$ & $5 / 10,6$ & 47 \\
\hline
\end{tabular}

Em todas as séries constata-se a utilização preferencial do clítico “o” em detrimento dos demais, e também o uso crescente ao longo das séries analisadas, aumentando em pouco mais de $20 \%$, da quinta série $(42,1 \%)$ à oitava $(78,8 \%)$. Os clíticos "te” e "lhe” não demonstram regularidade no uso ao longo das séries, pois, relacionando-se um ao outro, temos na quinta série o maior uso do "lhe” (36,9\%), na sexta série o maior uso do "te” (31,1\%) e a estabilidade de ocorrências entre ambos na oitava série, apresentando exatamente o mesmo índice percentual.

Esses resultados sugerem que, desde a $5^{\mathrm{a}}$ série, o clítico acusativo “o” está presente nas produções dos alunos e apresenta tendência crescente de uso, ultrapassando a marca dos 75\%. Mais uma vez, esses resultados se opõem àqueles relativos ao emprego dessa forma pronominal na posição de objeto direto de $3^{\mathrm{a}}$ pessoa e nos fazem inferir que, ao contrário do que se tem postulado, o clítico acusativo “o” não está em vias de desaparecer do Português Padrão. O que parece estar ocorrendo é uma especialização de uso ${ }^{9}$ que ocorre por meio de uma reanálise, ou seja, o clítico “o” deixa de ser usado em referência à $3^{\mathrm{a}}$ pessoa e começa a assumir a função específica de referência ao interlocutor.

Observemos o gráfico 2, abaixo, elaborado a partir da tabela 4, para melhor visualizarmos as proporções de uso referentes a cada clítico no preenchimento da posição de objeto na referência ao interlocutor.

\footnotetext{
${ }^{9}$ Conforme idéias expostas em Negrão \& Muller, 1994, que serão melhores exploradas ao final desta seção.
} 
Gráfico 2: Tipo de clítico X série escolar: modalidade formal.

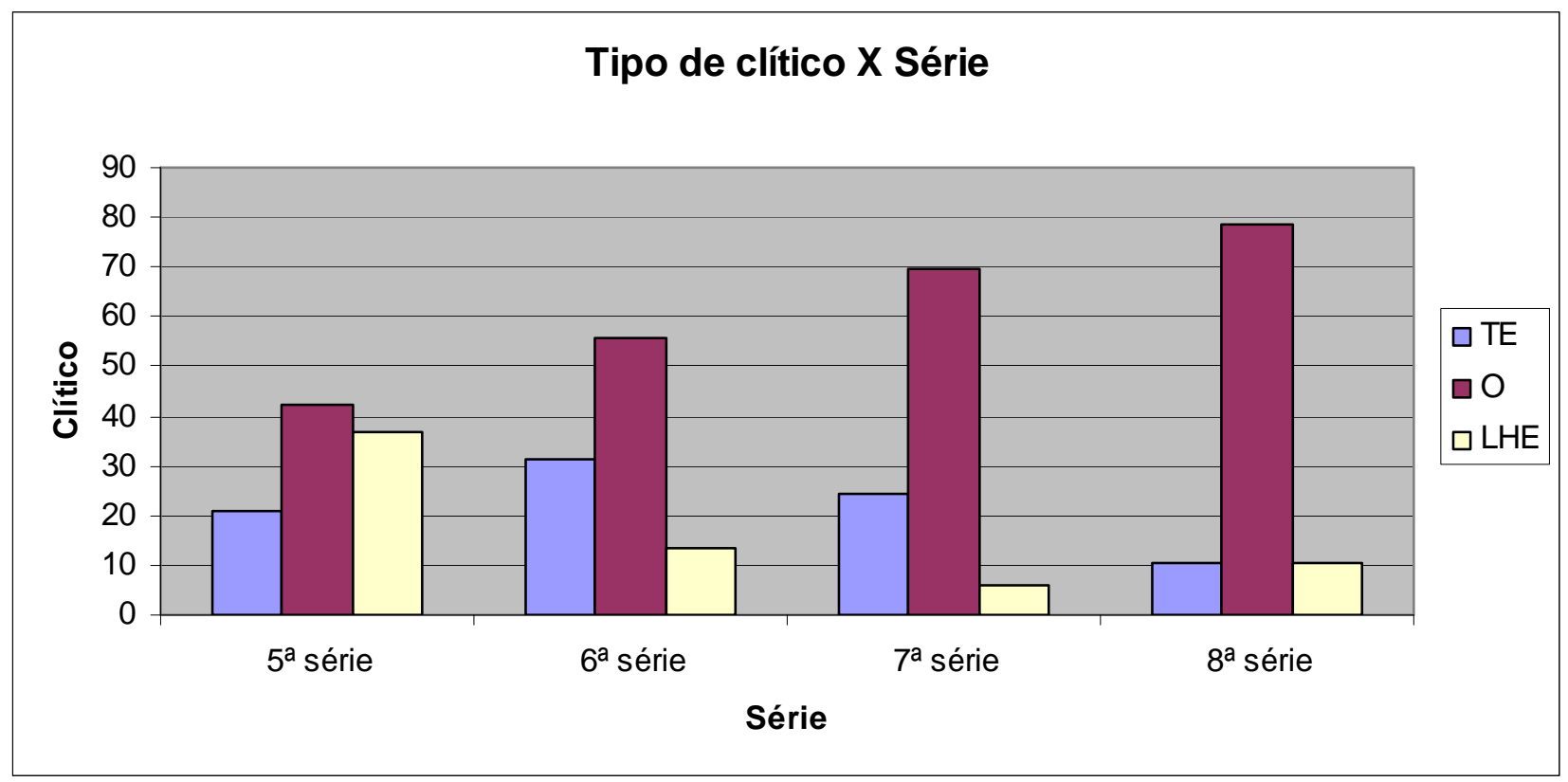

A questão está em saber se esse uso é restrito à modalidade formal, se, por ventura, encontraremos resultados semelhantes na modalidade informal analisada na próxima seção deste capítulo. Nunes, (1996), afirma que, quando houve a mudança da cliticização fonológica da esquerda para a direita, não havia como o onset da sílaba dos clíticos de terceira pessoa ser licenciado, o que poderia levar a um processo de reanálise para que o onset pudesse ser licenciado por outros processos, ou simplesmente poderia ocorrer o apagamento. Percebemos que, em especial o clítico “o”, quando utilizado em referência ao interlocutor nas situações formais, é a preferência dos alunos para o preenchimento da posição de objeto, o que poderia, então, ser um indício de reanálise.

A seguir, analisamos a posição dos clíticos em relação à estrutura verbal, com a finalidade de observar se há diferenças significativas entre os tipos de clíticos. 


\subsubsection{Posição do clítico em relação à estrutura verbal}

Dadas as significativas diferenças encontradas na análise das sentenças em detrimento das ocorrências de clíticos e outros tipos de termos no preenchimento da posição de objeto, julgamos pertinente diferenciar as ocorrências encontradas em grupos verbais (locuções verbais) e verbos simples, o que consta nas sub-seções demonstradas a seguir.

\subsubsection{Verbos Simples}

Nesta seção buscamos verificar a posição ocupada pelos clíticos em relação às formas simples dos verbos, e verificamos um total de 97 ocorrências. Todas elas se referem à posposição ou anteposição do clítico em relação ao verbo. Verifiquemos este fato na tabela que segue.

Tabela 5 - Tipo de clítico X posição com formas verbais simples: modalidade formal

\begin{tabular}{|l|c|c|c|c|}
\hline & TE & O & \multicolumn{1}{l|}{ LHE } & Total \\
\hline & Oc. / \% & Oc. / \% & Oc. / \% & Oc./ \% \\
\hline Anteposto & $29 / 31,2$ & $51 / 54,8$ & $13 / 14,0$ & 93 \\
\hline Posposto & $1 / 25$ & $3 / 75$ & $0 / 0$ & 4 \\
\hline Total & 30 & 54 & 13 & 97 \\
\hline
\end{tabular}

Observemos alguns exemplos de ocorrências com verbos simples dos clíticos pospostos e antepostos ao verbo:

a) Anteposto: 364 - Eu lhe convoco para uma reunião...;

395 - Mas te esperamos confiantes...;

480- Assim, nós o receberemos com uma grande festa. 
b) Posposto: 355 - Convoco-lhe para uma reunião...;

713 - Receberemos te na alegria de resolver...;

407- receberemos-lo com um café. (6 $6^{\mathrm{a}}$ série).

Na modalidade formal, houve a posposição do clítico ao verbo simples com as diferentes formas pronominais. No caso do clítico "o", registramos 3 ocorrências de posposição ${ }^{10}$, sendo duas em contexto de verbo em posição inicial da sentença, correspondentes aos exemplos 258 e 407 mencionados a seguir.

258 - convidamos-o ( $8^{\mathrm{a}}$ série);

407- receberemos-lo com um café. ( $6^{\mathrm{a}}$ série).

Houve uma única ocorrência de posposição do clítico “te”, e esta única ocorrência se dá com o verbo em posição inicial na sentença, conforme podemos verificar na ocorrência 713 (mencionado acima).

Quanto à anteposição, encontramos 5 casos com o clítico “te” com verbo em posição inicial de sentença, reproduzidos a seguir:

171- te receberemos com prazer. ( $7^{\mathrm{a}}$ série);

273- te receberemos ( $8^{\mathrm{a}}$ série);

467- te esperamos ( $6^{a}$ série);

548- te esperamos às oito horas. ( $6^{\mathrm{a}}$ série);

554- te convidamos para uma reunião ( $5^{a}$ série).

Houve apenas um caso de anteposição da forma "Ihe” (exemplo 709) neste contexto e 4 casos do clítico acusativo "o”, em contexto de verbo em posição inicial de sentença, conforme comprovam os exemplos reproduzidos abaixo.

\footnotetext{
${ }^{10}$ Das três ocorrências de posposição do clítico “o”, uma ocorre com a presença de atrator, é o caso do exemplo 392 - "e receberemo-os com café"
} 
709 - lhe receberemos com um café. (5ª série);

656- o receberemos com um café. ( $5^{\mathrm{a}}$ série);

085- o receberemos ( $7^{\mathrm{a}}$ série);

142- o receberemos a partir das oito ( $7^{\mathrm{a}}$ série);

331- o receberemos sexta-feira ( $8^{\mathrm{a}}$ série).

Nos demais casos de anteposição, verificamos a ocorrência de alguns elementos atratores do clítico, conforme reproduzimos logo abaixo:

a) Estrutura qu-:

051 - ...que o receberemos...(7 $7^{\mathrm{a}}$ série);

387- ...que te convocamos ... (6 $6^{\mathrm{a}}$ série);

b) Preposição:

127- ...para te pedir... (7ª série);

121 - para o encontrar ... ( $8^{\mathrm{a}}$ série);

451 - para lhe receber ... ( $6^{\mathrm{a}}$ série).

c) Pronome Pessoal: $\quad$ 293- Nós te convidamos ... ( $\quad$ (8 ${ }^{\mathrm{a}}$ série);

215- Nós o receberemos ... ( (8 ${ }^{\mathrm{a}}$ série);

131 - Eu lhe convido a participar... (7 $7^{\mathrm{a}}$ série).

d) Conjunção Coordenada: 321- ...e o receberemos aqui no bairro... (8 ${ }^{\mathrm{a}}$ série);

589 - ...e te convidamos para... (5 $5^{\text {a }}$ série);

213 - ... mas lhe esperamos no dia ... ( $7^{\mathrm{a}}$ série).

e) Advérbios:

383 - ...só te receberemos se pudermos... (8ª série);

311 - Hoje o convidamos... (8 $8^{\mathrm{a}}$ série);

195 - ...não lhe receberemos mal ... ( $7^{\mathrm{a}}$ série).

f) Outros:

332 - Quando te convidamos no dia ... (8 ${ }^{\mathrm{a}}$ série);

152 - ...mesmo assim o receberemos... (7 $7^{\mathrm{a}}$ série);

041- ... por isso o convidamos ... ( $7^{\mathrm{a}}$ série). 
Quanto aos exemplos acima mencionados, percebemos que não há diferenças na escolha dos clíticos em relação ao elemento que o atraia, ou seja, quando há um destes elementos atratores da próclise na sentença, este não faz distinção do tipo de clítico que ocorre junto a eles.

Passemos agora à análise da posição dos clíticos em relação aos grupos verbais.

\subsubsection{Grupos Verbais}

Nos grupos verbais verificamos um total de 150 ocorrências de clíticos. Buscamos verificar, nesta etapa, o comportamento dos clíticos com relação à posição ocupada por eles no grupo verbal, partindo da forma nominal encontrada em $\mathrm{V} 2^{11}$ (segundo verbo do grupo verbal) e da ocorrência de outros elementos que possam também influenciar a realização dos clíticos em determinadas posições. As três posições de colocação do clítico nos grupos verbais encontrados nas ocorrências são:

i) clítico posposto a V2 = [V1 V2 cl];

ii) clítico interposto aos dois verbos = [V1 cl V2];

iii) clítico anteposto ao verbo flexionado, ou seja, a V1 = [ cl V1 V2].

A seguir, temos um quadro geral de alguns exemplos de ocorrências dos clíticos com os grupos verbais, segundo a posição que ocupam na sentença.

a) Anteposto: 451 - também te queríamos conhecer...;

\footnotetext{
${ }^{11}$ V2 aqui significa o segundo verbo presente em um grupo verbal. Ele aparece na forma de infinito, gerúndio ou particípio, enquanto V1 é o verbo flexionado do grupo verbal.
} 
644 - Nós o mandaremos conhecer as necessidades...;

b) Posposto: 621 - Queríamos encontra-lo para debater...; 212 - Todos querem falar-lhe dos problemas...; 081 - Iremos receber-te atenciosamente....

c) Interposto: 352 - queríamos te convidar para um evento..; 455 - Por isso estou lhe convidando... 159- Estamos o convidando para uma reunião.

Observemos na tabela a seguir as proporções encontradas e suas respectivas porcentagens.

Tabela 6 - Tipo de clítico X Posição em grupos verbais: modalidade formal

\begin{tabular}{|l|c|c|l|l|}
\hline & \multicolumn{1}{l|}{ TE } & \multicolumn{1}{l|}{ O } & \multicolumn{1}{l|}{ Total } \\
\hline & N. de Oc. / \% & N. de Oc. / \% & N. de Oc. / \% & N. de Oc. / \% \\
\hline Anteposto & $1 / 25,0$ & $3 / 75,0$ & $0 / 0$ & 4 \\
\hline Posposto & $3 / 3,1$ & $90 / 91,8$ & $5 / 5,1$ & 98 \\
\hline Interposto & $22 / 45,8$ & $5 / 10,4$ & $21 / 43,8$ & 48 \\
\hline Total & 26 & 98 & 26 & 150 \\
\hline
\end{tabular}

Podemos notar, mais uma vez, que o comportamento do clítico “o” sobressai aos demais clíticos, diferentemente do que ocorreu com os verbos simples, pois esta forma tem o maior número de ocorrências (98) no grupo verbal. Quanto à colocação, a posposição ao V2 caracteriza o clítico “o” (91,8\%), diferenciando-o dos demais clíticos. A interposição parece ser a preferência para realização dos clíticos “te” e "lhe”, pois ambos contam com um uso equilibrado, na margem entre os 75\% e $80 \%$. A anteposição ao grupo verbal conta com um número inexpressivo de ocorrências, sendo 3 com a forma “o”, apenas 1 com a forma "te” e nenhuma ocorrência com "lhe”. Surpreendentemente, somente a forma "o” aparece com verbo 
em posição inicial de sentença. Os exemplos dos clíticos com estas estruturas, buscamos reproduzir logo a seguir:

307- o ouvimos dizer ( $8^{\mathrm{a}}$ série);

645- o estarei esperando ( $5^{\mathrm{a}}$ série);

Com relação à interposição ao grupo verbal, o clítico “o” apresentou 5 ocorrências, conforme os exemplos reproduzidos a seguir:

680 - vamos o receber com um café.. (6 $6^{\mathrm{a}}$ série);

635 - Nós estamos o convidando ( 6 a série);

372 - estou o convidando ( $6^{\mathrm{a}}$ série);

192 - Nossa comunidade está o convidando (7ª série);

066 - decidimos o convidar a essa reunião ( $7^{\mathrm{a}}$ série).

Uma vez que o clítico “o” novamente demonstra um comportamento diferenciado em relação aos demais, observemos agora a distribuição dos clíticos por posição e forma nominal do V2.

Na tabela abaixo, observamos o quadro geral dos clíticos e suas posições em relação à forma assumida V2 do grupo verbal. Uma vez que V2 é sempre uma forma nominal, as possibilidades de ocorrência para tal são três: infinitivo, gerúndio e particípio.

Tabela 7 - Forma nominal do $2^{\circ}$ verbos nos grupos verbais X posição do pronome clítico: modalidade formal

\begin{tabular}{|l|c|c|c|c|c|c|c|}
\hline & \multicolumn{2}{|c|}{ TE } & \multicolumn{2}{c|}{ O } & \multicolumn{2}{c|}{ LHE } & \\
\hline & Inf. / \% & Ger. / \% & Inf. / \% & Ger. / \% & Inf. / \% & Ger. / \% & Oc. \\
\hline Anteposição & $1 / 4,6$ & $0 / 0$ & $2 / 2,2$ & $1 / 12,5$ & $0 / 0$ & $0 / 0$ & 4 \\
\hline Posposição & $3 / 13,6$ & $0 / 0$ & $86 / 95,6$ & $4 / 50,0$ & $4 / 21,0$ & $1 / 14,3$ & 98 \\
\hline
\end{tabular}




\begin{tabular}{|l|c|c|c|c|c|c|c|}
\hline Interposição & $18 / 81,8$ & $4 / 100$ & $2 / 2,2$ & $3 / 37,5$ & $15 / 79,0$ & $6 / 85,7$ & 48 \\
\hline Total Oc./ \% & $22 / 100$ & $4 / 100$ & $90 / 100$ & $8 / 100$ & $19 / 100$ & $7 / 100$ & 150 \\
& & & & & & & \\
\hline
\end{tabular}

A tabela 7, acima, demonstra que não foi possível encontrar nenhuma ocorrência de clíticos em grupos verbais, com V2 no particípio. Os clíticos "te” e "lhe” ocorrem em posição interposta, independentemente da forma nominal de V2, já para o clítico “o” prevalece a posição posposta a V2 para a forma infinitiva. No caso do gerúndio, o clítico “o” aparece em posposição e anteposição.

A única ocorrência de anteposição com “te” refere-se a V2 infinitivo. Com “o” temos 2 ocorrências com V2 infinitivo e 1 com V2 no gerúndio. Esta única ocorrência de anteposição de “o” com gerúndio é bastante interessante, pois, não sendo esta forma verbal a forma propícia ao licenciamento do onset, é natural que o aluno busque esta posição para o clítico. Observemos esta ocorrência:

645 - Eu o estarei esperando ... (5ª série)

Verificamos que, nesta ocorrência, o clítico conta com um pronome pessoal que o atrai para si. Resta, então, saber o que ocorre nos outros casos de clítico “o” com a V2 no gerúndio.

Observamos que o maior número de ocorrência do clítico “o” está na posposição ao grupo verbal com V2 infinitivo, o que é bastante coerente, pois esta posição favorece o onset pela terminação deste tipo de verbo. Em oposição a isto, verificamos que o número de ocorrências deste clítico em outras posições, ou combinado com V2 no gerúndio, são bastante reduzidas, confirmando, também, a estabilidade deste clítico na posposição com infinitivo. A ocorrência abaixo demonstra outro caso de V2 gerúndio com a forma “o” posposta ao grupo verbal, encontrada na $7^{\mathrm{a}}$ série. 
207 - ...estamos convidando-o para... (7ª série)

Também nesta ocorrência, percebemos, em oposição às ocorrências deste mesmo clítico também posposto ao grupo verbal com V2 infinitivo, que não havendo como licenciar o onset, o clítico permanece em sua forma vocálica. Temos abaixo uma outra ocorrência com V2 infinitivo que demonstra o contrário disto:

002 - ... e vamos recebe-lo ... ( $7^{\mathrm{a}}$ série)

Neste caso, devido à assimilação da identidade fônica do fonema /r/ final do verbo, houve, então, um ambiente propício ao clítico de ter licenciado o seu onset, tomando assim a forma “lo”. Interessante observar que não há nenhum outro caso em que o clítico não ocorra desta forma quando posposto ao grupo verbal com um V2 no infinitivo. Resta saber se o mesmo poderá ser verificado na modalidade informal do discurso.

\subsubsection{Considerações finais sobre a modalidade formal}

Na modalidade formal do discurso foi possível percebermos a importância dada pelos alunos às formas clíticas e aos sintagmas nominais para referenciar-se ao interlocutor. Ao longo das 4 séries do Ensino Fundamental percebemos ainda que os clíticos gradativamente passam a ser mais utilizados, tendo seu auge na $7^{\mathrm{a}}$ série, o que parece indicar que a escola tem grande responsabilidade na aprendizagem destas estruturas.

Observamos que são 3 as formas utilizadas na referência ao interlocutor: "te”, "Ihe” e “o”. A forma acusativa “o” tem a preferência no uso, contando com um total de $61,5 \%$ de ocorrências (alcançando expressivos 78,8\% na 8a série), deixando as formas "te” e "lhe” para 
trás, com percentuais bastante parecidos, como podemos verificar a seguir, nos exemplos transcritos.

$$
\begin{aligned}
& \text { 307- o ouvimos dizer ( } 8^{\mathrm{a}} \text { série); } \\
& 680 \text { - vamos o receber com um café.. (6 } 6^{\mathrm{a}} \text { série); } \\
& 207 \text { - ...estamos convidando-o para... (7 } 7^{\mathrm{a}} \text { série) } \\
& 002 \text { - ... e vamos recebe-lo ... (7 } 7^{\mathrm{a}} \text { série) }
\end{aligned}
$$

No que se refere à utilização do clítico “o”, em Duarte (1986), verificamos a idéia de que esta forma, quando em referência à terceira pessoa, está desaparecendo, sobretudo no que se refere à língua falada. Cordeiro (2004) também afirma que o clítico acusativo de $3^{\text {a }}$ pessoa somente pode ser adquirido via instrução formal. No entanto, percebemos aqui sua relevância para a referência à $2^{\mathrm{a}}$ pessoa do discurso, pois nosso estudo revela uma grande incidência de uso para uma situação formal de interlocução na escrita, o que pode ser um indicativo de uma reorganização do sistema. O pronome clítico “o”, junto a formas verbais simples, demonstra maior uso na anteposição ao verbo (próclise), tendo sido observadas apenas 3 ocorrências de ênclise. Com relação aos clíticos nos grupos verbais, a forma “o” demonstrou um comportamento oposto ao das demais formas clíticas: conta com um maior uso na posposição, enclítico a V2 (91,8\%).

Verificamos ainda que o contexto fonológico não é o único fator de força para a aprendizagem dos clíticos, uma vez que isto ocorre primeiro na escrita, e ao produzi-los, o onset não é um condicionante de força, (como se percebe na ocorrência 680), nem tão pouco a presença de uma partícula atratora (tal como ocorre em 002). 


\subsection{Parte II: Modalidade Informal}

Na modalidade informal, foram computadas 929 ocorrências de realização do objeto direto na referência ao interlocutor, um número, conforme já mencionado, superior ao encontrado na modalidade formal.

Observaremos, nesta seção, se os mesmos tipos de resultados encontrados para a modalidade formal, nos testes aplicados, repetem-se na modalidade informal, e, a partir do contraste, perceberemos os fatores que são mais influenciados por esta mudança na modalidade discursiva, de modo que se possa, a partir disso, investigar o sistema pronominal do PB, e responder algumas das questões reveladas anteriormente.

\subsubsection{Realização do complemento verbal}

Nesta modalidade discursiva, constatamos as seguintes proporções para realização do objeto direto em referência ao interlocutor, nas séries analisadas do Ensino Fundamental, conforme demonstram as tabelas abaixo:

Tabela 8: Formas de objeto direto: número de ocorrências e percentual : modalidade informal

\begin{tabular}{|l|l|l|l|l|}
\hline Clítico & Pr. tônico & SN & Objeto nulo & Total \\
\hline N. oc. / \% & N. oc. / \% & N. oc. / \% & N. oc. / \% & N. oc. \\
\hline 772 / 83,2 & 114 / 12,2 & $13 / 1,4$ & $30 / 3,2$ & 929 \\
\hline
\end{tabular}

a) Clítico: $\quad 211$ - gostaria de poder te conhecer;

338 - Por isso estou lhe convidando. 
b) Pronome Tônico: 027 - Ouvi você dizer ${ }^{12}$;

049 - Achei você muito bonita ${ }^{13}$.

c) Sintagma Nominal: 448 - Espero a menina mais bonita da cidade;

036 - Estou ansioso para encontrar a garota dos meus sonhos.

d) Objeto Nulo: 554- Eu espero ø até o final da tarde;

718 - ..e espero ø com muita saudade...

Na modalidade informal o clítico é a forma preferencial do objeto direto em referência ao interlocutor, com $83,2 \%$ (bastante superior aos $41,5 \%$ da modalidade formal). As demais formas têm índices baixíssimos de freqüência, sendo que o emprego do pronome tônico supera o do objeto nulo e do sintagma nominal, o que é bastante curioso, pois o sintagma nominal, na modalidade formal, tem índices altos, ligeiramente superiores aos números dos clíticos. Outro fato que merece menção, com relação aos pronomes tônicos, é que, ao contrário do que se verificou na modalidade formal, aqui verificou-se apenas o uso da forma “você”.

Observemos agora, no gráfico abaixo as proporções constatadas na tabela 15, a respeito da distribuição dos diferentes tipos de objeto por série:

\footnotetext{
${ }^{12}$ A ocorrência 027 corresponde a um caso de port-manteau sintático, pois o verbo da oração subordinada projeta uma estrutura com agente, o qual é objeto do verbo da oração matriz (cf. Duarte, 1999).

${ }^{13}$ A ocorrência 049 corresponde a um caso de small clause, pois verificamos um verbo seguido se seu objeto direto e um predicativo deste objeto na sentença.
} 
Gráfico 3: Formas de objeto direto X séries escolares: modalidade informal

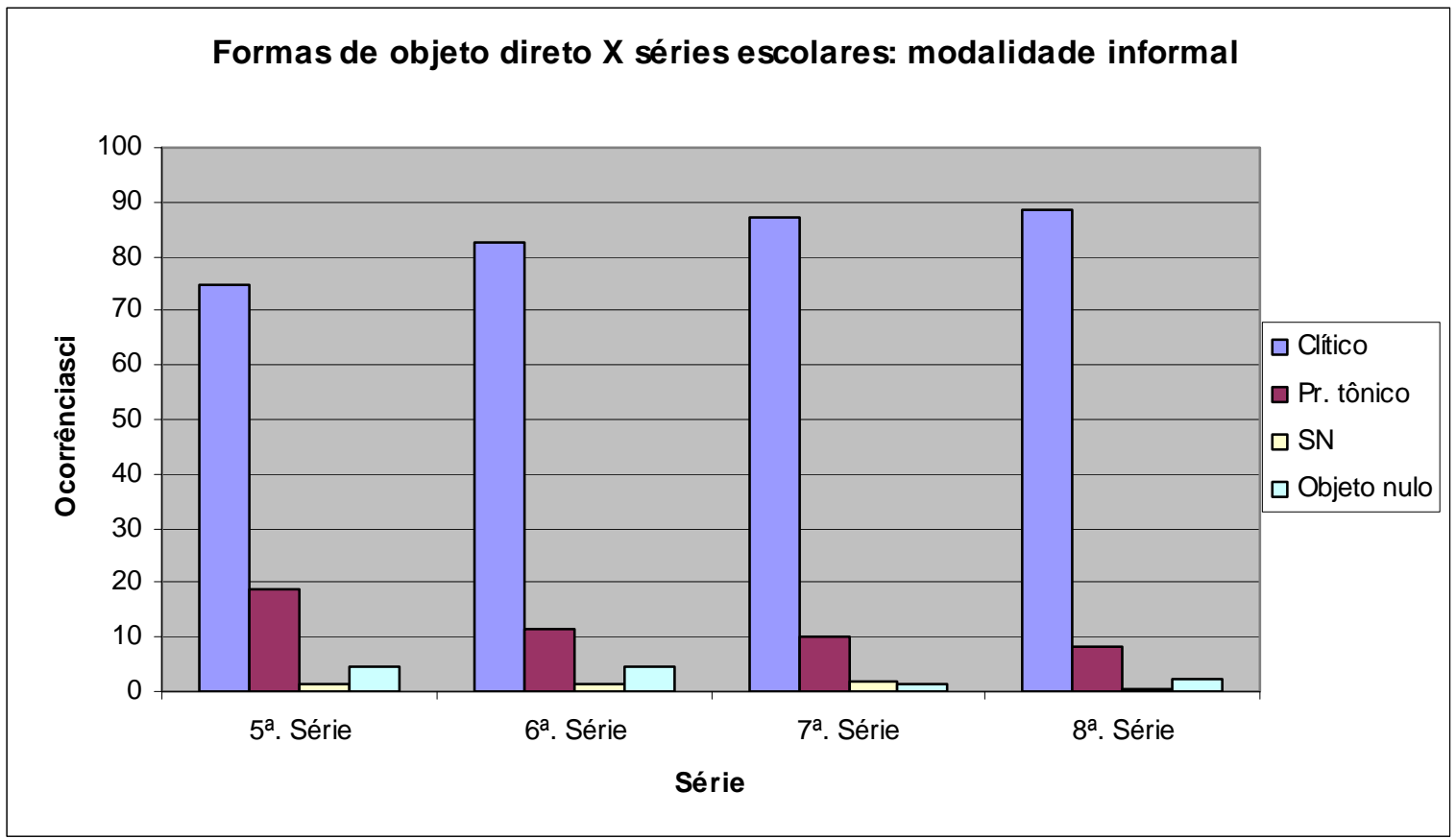

Na tabela abaixo verificamos as porcentagens demonstradas no gráfico acima e o número de ocorrências correspondentes a cada uma destas porcentagens.

Tabela 9: Formas de objeto direto X séries escolares: modalidade informal

\begin{tabular}{|l|l|l|l|l|l|}
\hline $\begin{array}{l}\text { Formas OD/ } \\
\text { Série }\end{array}$ & Clítico & Pr. tônico & SN & Objeto nulo & Total \\
\hline & N. oc. / \% & N. oc. / \% & N. oc. / \% & N. oc. / \% & N. oc. \\
\hline $\mathbf{5}^{\text {a. Série }}$ & $179 / 74,0$ & $47 / 19,5$ & $4 / 1,6$ & $12 / 4,9$ & 242 \\
\hline $\mathbf{6}^{\text {a. Série }}$ & $162 / 82,6$ & $22 / 11,3$ & $3 / 1,5$ & $9 / 4,6$ & 196 \\
\hline $\mathbf{7}^{\text {. }}$ Série & $219 / 87,0$ & $25 / 9,9$ & $5 / 1,9$ & $3 / 1,2$ & 252 \\
\hline $\mathbf{8}^{\text {a. Série }}$ & $212 / 88,7$ & $20 / 8,4$ & $1 / 0,4$ & $6 / 2,5$ & 239 \\
\hline
\end{tabular}

Os dados mostram uso crescente do clítico e uso decrescente do pronome tônico, o que sugere uma substituição de formas pronominais ao longo das séries do Ensino Fundamental. O uso decrescente do objeto nulo indica que o contato com o clítico na escola leva ao preenchimento da posição de objeto. A oscilação no caso do sintagma nominal e a queda do 
pronome tônico sugerem que o preenchimento do objeto se faz com o clítico. Isso significa que o crescimento do índice percentual do clítico se deve à diminuição do emprego do pronome tônico e do objeto nulo. Resta saber que tipo de clítico aparece nesses contextos.

\subsubsection{Tipo de clítico na função de objeto direto em referência ao}

\section{interlocutor}

Com relação ao tipo de clítico utilizado na referência ao interlocutor, temos, também na modalidade informal do discurso nos testes, o uso das formas "te" e "o", de função acusativa e "lhe", de função original canônica dativa. Podemos observar exemplos de sentenças com clíticos nesta modalidade e a freqüência de uso desses clíticos na tabela 16 abaixo.

Tabela 10: Tipo de clítico na função de objeto direto em referência ao interlocutor: modalidade informal

\begin{tabular}{|l|l|l|l|}
\hline TE & O & LHE & Total \\
\hline N. de Oc. / \% & N. de Oc. / \% & N. de Oc. / \% & N. de Oc. \\
\hline $652 / 84,4$ & $87 / 11,3$ & $33 / 4,3$ & 772 \\
\hline
\end{tabular}

a) TE: 575 - Eu te amo profundamente;

356 - Te encontrarei em uma festa.

b) O: 464 - Será bom conhece-la...;

224- Eu a espero amanhã.

c) LHE: 487 - mas não lhe conhecia...;

493 -posso lhe esperar até o anoitecer. 
Na modalidade informal, reina o clítico “te”, com 84,4\%. As demais formas pronominais têm índice baixo, o que mostra que não comprometem o sistema pronominal em referência ao interlocutor. De fato, o clítico acusativo “o” apresenta-se com 11,3\% e o clítico "Ihe” com 4,3\%. Esses números surpreendem, pois algumas dissertações, artigos e teses (ver o capítulo introdutório, sobre as questões teóricas que norteiam este estudo) vêm mostrando a queda de "o" e o avanço de "lhe" nesse contexto.

Isto confirma a suposição de Ramos (1999) sobre a divisão das gramáticas do PB contemporâneo e a situação dos clíticos nestas variedades: propõe a autora que no eixo RioSão Paulo desenvolveu-se uma gramática em que a forma tônica "você" é introduzida no lugar de “tu”. Assim, com a forma generalizada “você”, de tratamento universal, é introduzida a forma "te" para situações de intimidade e informalidade (o que facilmente se confirma na tabela 16 logo acima) e a forma "lhe” permanece em seu uso canônico (i.e., na função de objeto indireto), daí um número tão reduzido de ocorrências encontradas em nosso corpus na modalidade informal.

No que concerne ao clítico “o”, é de se supor que o seu uso seja veiculado pela escola, uma vez que se procura associar a forma nominativa "tu” à forma acusativa "te” e a forma nominativa “você” à forma acusativa “o”. Para observar o peso da ação da escola, analisamos o clítico por série escolar, e os resultados de ocorrências e freqüências podem ser constatados na próxima tabela que segue.

Tabela 11 - Tipo de clítico por série escolar : modalidade informal

\begin{tabular}{|l|l|l|l|l|}
\hline Clítico / Série & TE & O & LHE & Total \\
\hline & N. oc. / \% & N. oc. / \% & N. oc. / \% & N. oc. \\
\hline $5^{\text {a }}$ série & $146 / 81,5$ & $22 / 12,4$ & $11 / 6,1$ & 179 \\
\hline $\mathbf{6}^{\text {a }}$ série & $141 / 87,0$ & $18 / 11,2$ & $3 / 1,8$ & 162 \\
\hline $\mathbf{7}^{\text {a }}$ série & $175 / 80,0$ & $31 / 14,1$ & $13 / 5,9$ & 219 \\
\hline $\mathbf{8}^{\text {a }}$ série & $190 / 89,7$ & $16 / 7,5$ & $6 / 2,8$ & 212 \\
\hline
\end{tabular}


De acordo com os dados da tabela acima, o clítico “te” sofre queda na 7a série (80\%) ao passo que os clíticos “o” e "Ihe” apresentam aumento de freqüência, 14,1\% e 5,9\%, respectivamente. Estes números poderiam levar a inferir que a escola não só municia o aluno a usar o clítico, mas o leva a correlacionar a forma "você" ao clítico acusativo. Entretanto, os dados referentes à $5^{\mathrm{a}}$ série mostram que os valores são bastante próximos aos da $7^{\mathrm{a}}$ série, o que nos leva a inferir que a escola não parece interferir na escolha do clítico acusativo em referência ao interlocutor na modalidade informal da língua.

Observe-se ainda que na $8^{\mathrm{a}}$ série, a queda dos clíticos “o” e de "lhe” é bastante acentuada, e, por conseguinte, é acentuado o aumento do clítico "te”, que atinge admiráveis 89,7\%. O que os dados parecem indicar é que a oscilação ocorrida na $7^{\mathrm{a}}$ série, período em que é estudada a sintaxe dos pronomes, deriva do fato de o aluno não associar o uso do clítico à modalidade discursiva em questão. Em outras palavras, a queda da forma “o” na 8 a série (7,5\%), bem como a do clítico "lhe” (2,8\%), respectivamente, mostra que o clítico de $3^{\text {a }}$ pessoa é bastante residual na modalidade informal do discurso. A escolha do clítico "te” na modalidade informal parece se definir na $8^{\text {a }}$ série, momento em que o clítico "te” passa a reinar de forma quase absoluta.

Se levarmos em conta que na modalidade formal o clítico “o” aproxima-se dos 62\%, temos aqui a relação entre modalidade discursiva e uso pronominal: na modalidade formal impera o clítico "o" e na modalidade informal impera o clítico "te”, ainda que, de acordo com as gramáticas normativas, o uso de "você", que aparece categoricamente nos textos, devesse detonar o uso de “o”, independentemente da modalidade discursiva.

A seguir, analisamos a posição dos clíticos em relação à estrutura verbal. 


\subsubsection{Posição do clítico em relação à estrutura verbal}

\subsubsection{Verbos Simples}

Nesta seção buscamos verificar a posição ocupada pelos clíticos em relação às formas simples dos verbos e aos grupos verbais. Fiquemos, inicialmente, com os verbos simples, verificando inicialmente os tipos de sentenças que trazem estas formas e a tabela 18, que contém as respectivas freqüências.

a) Anteposto: 264 - Eu lhe vi no clube...;

475 - Te espero ate a noite...(7 $7^{a}$ série);

080- ..., a receberei com muito carinho ( $8^{\mathrm{a}}$ série $)^{14}$.

b) Posposto: 255 - Esperarei-lhe até o anoitecer ( $7^{\text {a }}$ série) ...;

364 - ...,esperarei-te ate a noite...(7 $7^{\mathrm{a}}$ série $) .$. ;

573 - Vi-a no clube outro dia (6 $6^{\text {a }}$ série);

Tabela 12 - Tipo de clítico X posição com formas verbais simples: modalidade informal

\begin{tabular}{|l|l|l|l|l|}
\hline & TE & O & LHE & Total \\
\hline & N. de Oc. / \% & N. de Oc. / \% & N. de Oc. / \% & N. de Oc \\
\hline Anteposto & $430 / 99,7$ & $49 / 90,7$ & $18 / 94,7$ & 497 \\
\hline Posposto & $1 / 0,3$ & $5 / 9,3$ & $1 / 5,3$ & 7 \\
\hline Total de Oc./ \% & $431 / 100$ & $54 / 100$ & $19 / 100$ & 504 \\
\hline
\end{tabular}

Todos os clíticos aparecem majoritariamente antepostos ao verbo simples. Entretanto, devemos observar que a forma "te" ocorre proclítica ao verbo de modo muito acentuado, atingindo o altíssimo índice de 99,7\%. Ou seja, a sua posição proclítica é quase categórica. As ocorrências de número 255 e 364, citados nos exemplos acima, demonstram que as duas

\footnotetext{
${ }^{14}$ Percebemos nesta ocorrência, que seria um típico contexto de mesóclise, a preferência pela ênclise do clítico junto ao verbo no futuro do presente do indicativo, o que vem a mostrar que, ao contrário do que prescreve a gramática tradicional, no uso corrente da língua.
} 
únicas ocorrências de clítico "Ihe” e "te” pospostos ao verbo estão na $7^{a}$ série, o que talvez resulte da aprendizagem que se dá nesta série dos clíticos e suas colocações conforme a gramática tradicional. Entre as duas outras formas pronominais, “o” é a que mais se apresenta enclítico ao verbo, com 9,3\%. Portanto, no quesito posição do clítico em relação ao verbo simples, apesar de a preferência ser pela próclise, no que se refere ao clítico “o”, este se distancia dos demais, pois é o que mais aparece na posição menos natural do Português Brasileiro, a posição enclítica ao verbo.

Observemos a posição dos clíticos em relação à série escolar para averiguar se a instrução escolar, incide na colocação pronominal, em face das regras normativas da gramática. Para isso, centramos a atenção nos dados numéricos da anteposição do clítico às formas verbais simples.

Com relação às cinco ocorrências de posposição do clítico “o”, três enquadram-se em contexto de verbo em primeira posição absoluta na sentença (o que corresponde aos exemplos 231, 349 e 462 transcritos).

231- esperarei-a ate o anoitecer ( $7^{\mathrm{a}}$ série);

349- achei-a muito bonita. ( $7^{\mathrm{a}}$ série);

462- esperarei-a até o anoitecer ( $7^{\mathrm{a}}$ série).

Saliente-se a presença de dois casos de futuro do presente, tempo que, conforme prescreve a gramática normativa, deveria ocorrer a mesóclise. Nos dados analisados não se verificou nenhuma ocorrência de mesóclise, nem mesmo nos casos em que o verbo ocupava a $1^{\mathrm{a}}$ posição na sentença.

As outras duas ocorrências de ênclise deste clítico ao verbo ocorrem na presença de elementos atratores, como se pode verificar nos exemplos 766 e 959. Nestes casos também 
verificou-se a presença de conjunção coordenativa antecedendo o verbo, assim como a ênclise do clítico ao verbo, conforme os exemplos reproduzidos abaixo.

766- pois achei-a muito bonita. (5 série);

959- e esperarei-a ao anoitecer. (5ª́rie).

Ressalte-se que os exemplos citados não configuram-se em contexto de onset silábico, uma vez que, para que haja o licenciamento do ataque silábico, é necessário que haja um fonema que corresponda à regra de assimilação para tais contextos, antecedendo o clítico, o que não se verifica nestes casos. Provavelmente, a intervenção da escola é a responsável pela produção destes tipos de sentença, pois coloca em conflito as regras gramaticais internalizadas pelo aluno em tenra idade, no processo pelo qual passou na aquisição da linguagem, e a aprendizagem formalizadas pela escola, da colocação destas estruturas clíticas.

Surpreendentemente, foram encontradas ocorrências do clítico “o” anteposto ao verbo, em posição inicial da sentença, ou seja, sem nenhum outro elemento que o anteceda, conforme verifica-se a seguir.

172- a achei muito bonita. (8 ${ }^{\mathrm{a}}$ série);

174- a espero até o anoitecer.( $8^{\mathrm{a}}$ série);

438 - a achei muito bonita. ( $7^{\mathrm{a}}$ série).

Nestes casos o onset não é licenciado, pois não há um elemento antecedente que possa impor, por identidade fônica, a regra de assimilação que se prevê para estes casos, ou seja, um fonema $/ \mathrm{r} / \mathrm{s} / \mathrm{s} /$ ou $/ \mathrm{m} /$ final que pudesse licenciar o ataque da sílaba do clítico, fazendo com que o mesmo ocorra em sua forma vocálica.

O único caso encontrado de "Ihe” posposto ao verbo verifica-se também na sentença em que o verbo ocupa a posição inicial. Também neste caso o verbo está no futuro do 
indicativo. Este é o caso do exemplo 255 encontrado na $7^{\text {a }}$ série, conforme podemos verificar abaixo.

255 - Esperarei-lhe até o anoitecer ( $7^{\mathrm{a}}$ série);

Em relação ao clítico “te”, verificamos 103 ocorrências de próclise com o verbo na $1^{\mathrm{a}}$ posição na sentença. Observamos estas ocorrências distribuídas em todas as séries do Ensino Fundamental, nas seguintes proporções:

i) $\quad 5^{\text {a }}$ série: 16 ocorrências, do total de 96 encontradas nesta série, o que corresponde a $16,6 \%$ do total;

ii) $\quad 6^{\text {a }}$ série: 18 ocorrências, do total de 87 encontradas nesta série, o que corresponde a $20,7 \%$ do total;

iii) $\quad 7^{\text {a }}$ série: 26 ocorrências, do total de 111 encontradas nesta série, o que corresponde a $23,5 \%$ do total;

iv) $\quad 8^{a}$ série: 46 ocorrências, do total de 136 encontradas nesta série, o que corresponde a $31,6 \%$ do total.

Reproduzimos abaixo alguns exemplos de próclise do clítico “te” em sentenças com verbo na primeira posição:

007- te vi ontem ( $8^{\mathrm{a}}$ série);

085- te espero no lugar... ( $8^{\mathrm{a}}$ série);

66- te achei muito bonita ( $8^{\mathrm{a}}$ série).

Em relação ao clítico "Ihe”, também no contexto de verbo na primeira posição na sentença, foram encontrados 3 casos de próclise, do total de 18 ocorrências, perfazendo assim 
16,6\% do total. Todos os demais casos contem um elemento qualquer, tais como advérbios, adjetivos, pronomes pessoais, entre outros.

139- lhe vi ontem ( $8^{\mathrm{a}}$ série);

354-lhe achei muito bonita ( $7^{\mathrm{a}}$ série);

892- lhe achei muito bonita ( $5^{\mathrm{a}}$ série).

De todas as ocorrências dos clíticos com verbos simples, extraímos alguns exemplos em que se observa a existência de algum outro elemento em primeira posição na sentença. Buscamos, para melhor ilustrar, um exemplo com cada tipo de clítico produzido na referência ao interlocutor.

\section{a) Estrutura qu-:}

473 - ...que te amo...(7 $7^{\text {a }}$ série);

621- ...que a vi ... (6 $6^{\text {a }}$ série);

748 - quando lhe vi no clube... ( $5^{\mathrm{a}}$ série);

\section{b) Preposição:}

454- ...para te pedir... (7ª série);

121 - de a encontrar ... ( $8^{\mathrm{a}}$ série);

651 - para lhe ver no dia ... (6 $6^{\mathrm{a}}$ série).

\section{c) Pronome Pessoal:}

077- Eu te amo ... ( ( $^{\mathrm{a}}$ série);

083- Eu a amo ... ( (8 ${ }^{\mathrm{a}}$ série);

381 - Eu lhe vi... (7ª série).

\section{d) Conjunção Coordenada:}

018- ...e te achei muito bonita... ( $8^{\mathrm{a}}$ série);

509 - ...e a vi. (6 $6^{\text {a }}$ série);

200 - pois lhe vi ... ( $8^{\mathrm{a}}$ série). 


\section{e) Advérbios:}

483 - ...já te conheço... (7 $7^{\mathrm{a}}$ série)

611 - Ontem a vi no clube.. (6 $6^{\mathrm{a}}$ série);

495 - ...não lhe conhecia ... ( $7^{\mathrm{a}}$ série).

\section{f) Outros:}

132 - mesmo te encontrando ... ( $8^{\mathrm{a}}$ série)

852 - por isso a amo... (5 $5^{\text {a }}$ série)

Passemos agora à análise dos grupos verbais, de forma que possamos estabelecer um contraste entre as diferentes composições verbais e oracionais, na verificação do comportamento dos clíticos em relação a estes contextos sintáticos.

\subsubsection{Grupos Verbais}

Nesta seção, analisaremos a posição dos clíticos em relação aos grupos verbais. Temos abaixo a tabela 21 que demonstra as proporções dos clíticos nos grupos verbais, segundo a forma nominal em que V2 (segundo verbo) se encontra.

Tabela 13 - Forma nominal do $2^{\circ}$ verbos nos grupos verbais X Tipo de pronome clítico: modalidade informal

\begin{tabular}{|l|l|l|l|l|}
\hline & TE & O & LHE & Total \\
\hline & N. de Oc./ \% & N. de Oc./ \% & N. de Oc./ \% & N. de Oc. \\
\hline V2 Infinitivo & $184 / 81,5$ & $32 / 14,1$ & $10 / 4,4$ & 226 \\
\hline V2 Particípio & $7 / 100$ & $0 / 0$ & $0 / 0$ & 7 \\
\hline V2 Gerúndio & $30 / 85,8$ & $1 / 2,8$ & $4 / 11,4$ & 35 \\
\hline Total & 221 & 33 & 14 & 268 \\
\hline
\end{tabular}


Percebemos a grande incidência de "te" com verbos no infinitivo (81,5\% das ocorrências de infinitivo), seguido do clítico “o”, em menor proporção (14,1\%) e do "lhe” (4,4\% do total). Observamos que a combinação de V2 gerúndio conta com um número razoável de ocorrências com clítico “te” (30 ocorrências do total de 35) e uma ainda menor proporção de uso de “o” (1 ocorrência) e "Ihe” (4 ocorrências).

O fato mais curioso encontra-se no clítico “te”, que é o único que aparece na estrutura auxiliar + particípio. Observemos, nas ocorrências extraídas da tabela 13 acima, o comportamento do grupo verbal nestas 7 ocorrências:

a) $8^{\text {a }}$ série: 002 - Foi bom ter te visto...;

032 - ...sem ao menos ter te conhecido...;

087 - Eu nunca havia te visto...

162 - Nunca tinha te visto...;

b) $7^{\text {a }}$ série: $\quad 337-$...sem ter te conhecido.

c) 5 série: $\quad 797$ - ter te conhecido.

922- jurava já ter te visto

$\mathrm{Na}$ estrutura em que encontramos auxiliar + V2 particípio, o clítico "te” ocorre categoricamente na posição intermediária, ainda que, na sentença, estejam presentes possíveis atratores para próclise: observemos o advérbio “nunca” nos exemplos 087 e 162 e o advérbio aspectual "já” no exemplo 922 acima. As formas clíticas “o” e "Ihe” não aparecem nas estruturas verbais formadas de verbo auxiliar + V2 particípio.

Na tabela 14 abaixo, verificamos as combinações “tipo de clítico”, “forma de V2” e "posição dos clíticos”. 
Tabela 14 - Forma nominal do $2^{\circ}$ verbos nos grupos verbais X posição do pronome clítico: modalidade informal

\begin{tabular}{|l|l|l|l|l|l|l|l|l|}
\hline & \multicolumn{3}{|c}{ TE } & \multicolumn{2}{c|}{ O } & \multicolumn{2}{c|}{ LHE } & Total \\
\hline & Inf. & Ger. & Part. & Inf. & Ger. & Inf. & Ger. & \\
\hline Anteposição & $1 / 0,6$ & $1 / 3,4$ & $0 / 0$ & $0 / 0$ & $0 / 0$ & $0 / 0$ & $0 / 0$ & $2 / 0,7$ \\
\hline Posposição & $1 / 0,6$ & $0 / 0$ & $0 / 0$ & $30 / 93,7$ & $1 / 100$ & $1 / 10,0$ & $1 / 25,0$ & $34 / 12,7$ \\
\hline Interposição & $182 / 98,8$ & $29 / 96,6$ & $7 / 100$ & $2 / 6,3$ & $0 / 0$ & $9 / 90,0$ & $3 / 75,0$ & $232 / 86,6$ \\
\hline Total \% & $184 / 100$ & $30 / 100$ & $7 / 100$ & $32 / 100$ & $1 / 100$ & $10 / 100$ & $4 / 100$ & $268 / 100$ \\
& & & & & & & & \\
\hline
\end{tabular}

Verifiquemos, a seguir, algumas das ocorrências retiradas dos percentuais indicados na tabela acima:

a) Anteposto: 451 - também te quero conhecer muito...(7ª série); 715 - e te vi conversando (6 $6^{\mathrm{a}}$ série).

b) Posposto: 621 - Queria encontra-la no lugar que... (5 ${ }^{\text {a }}$ série); 212 - Eu quero encontrar-lhe no clube... ( $7^{\mathrm{a}}$ série); 081 - Irei receber-te com carinho... (8 ${ }^{\mathrm{a}}$ série).

c) Interposto: 352 - estou te pedindo uma chance... (6 $6^{\mathrm{a}}$ série); 368 - Eu vi lhe passando... (6 $6^{\text {a }}$ série); 159- Estaria a convidando se não fosse... ( $8^{\mathrm{a}}$ série);

Percebemos que o clítico “te” aparece majoritariamente na posição intermediaria ao grupo verbal, independentemente da forma nominal do V2 (98,8\% no caso de V2 infinitivo, 96,6\% com gerúndio e 100\% com V2 no particípio). Somente o clítico “te” ocorre no particípio, fato que não se verifica nem na modalidade formal do discurso. A posição 
proclítica e a enclítica (ao grupo verbal), ao que tudo indica, não são favoráveis para o aparecimento do clítico “te”.

A posposição do clítico "lhe” ao grupo verbal também apresenta um número bastante reduzido de ocorrências (2 ao todo, sendo uma com V2 infinitivo e outra com V2 no gerúndio). Há neste contexto, a preferência pela interposição, além de termos verificado apenas dois casos de posposição e nenhum para a anteposição.

Na tabela 22, percebemos, ainda, que os clíticos “te” e "lhe” interpostos aos grupos verbais com V2 no infinitivo e gerúndio comportam-se de modo semelhante, pois, se comparadas as porcentagens, nas devidas proporções, revela-se a semelhança numérica entre elas. O mesmo não pode ser observado com o clítico “o”, pois conta com um número baixíssimo de interposições, o que nos revela algumas particularidades deste clítico, caso que será melhor analisado nas seções que seguem. A ênclise ao V2 é a posição preferida para o clítico “o”, pois não ocorreu nenhum caso de próclise e somente constatou-se duas ocorrências de interposição do clítico quando o V2 está no infinitivo.

Tendo em vista a grande preferência pela ênclise do clítico “o” ao segundo verbo (V2) do grupo verbal, decidimos analisar também o contexto em que aparecem. A posposição do clítico “o” perfaz o total de 31 ocorrências, distribuídas entre grupos verbais com V2 infinitivo, sem a presença de preposição (24 ocorrências) e com a presença da preposição (6 ocorrências).

Logo a seguir, podemos verificar 24 ocorrências do clítico “o” posposto ao grupo verbal.

027 - Vou espera-la no clube...(8 ${ }^{\mathrm{a}}$ série);

092 - Irei espera-la onde combinamos...(8 ${ }^{a}$ série); série);

173- ...adoraria conhece-la ...(8 ${ }^{\mathrm{a}}$ série); série);
587 - ... eu posso conhece-la ...(6 $6^{\mathrm{a}}$ série); 652 - Eu quero encontra-la ...(6 $6^{\mathrm{a}}$ $680-\ldots$ se posso conhece-la ...(6 $6^{\mathrm{a}}$ 
176 - ...eu queria conhece-la ...(8 $8^{\mathrm{a}}$ série);

707 - Quero encontra-la ...(5 série);

281 - ... eu queria saber se podia conhece-la ...(7 $7^{\mathrm{a}}$ série $) ; 712$ - ... se posso conhece-la ...(5 $5^{\mathrm{a}}$ série);

339 -...quero conhece-la amanhã...(7ª série);

722 - ...e queria encontra-la

série);

340 - ...vou espera-la até ... (7 $7^{\mathrm{a}}$ série);

723 - vou espera-la até o anoitecer...(5 $5^{\mathrm{a}}$

série);

347 - ... adoraria conhece-la ... (7 $7^{\mathrm{a}}$ série);

755 - ... que fui ajuda-la ...(5 $5^{\text {a }}$ série);

351 - ...e queria conhece-la ... (7 $7^{\mathrm{a}}$ série);

813 - Eu poderia conhece-la ...(5

série);

405 - ...e queria conhece-la...(7 $7^{\text {a }}$ série);

827 - Vou espera-la ...(5ª série);

438 - ...eu quero conhece-la muito bem... ( $7^{\text {a }}$ série);

832 - Quero encontra-la ...(5 $5^{\mathrm{a}}$ série).

489 - ... vou espera-la até o anoitecer ...(7 $7^{\mathrm{a}}$ série);

603 - Eu quero conhece-la ... (6 ${ }^{\mathrm{a}}$

série);

Das 24 ocorrências de ênclise na estrutura V1 + V2, 11 acham-se em contexto de verbos em $1^{a}$ posição na sentença. As demais 13 ocorrências manifestam um elemento que precedo o verbo: 4 ocorrências de conjunção integrante (exemplos 281, 680, 712, 755), 3 ocorrência de conjunção coordenativa (exemplos 351, 405, 722) e 6 ocorrências de pronome pessoal (ex 176, 438, 587 603, 652, 813).

Na estrutura V1 + preposição + V2 também se verificou o uso categórico da ênclise, no caso do clítico “o”, a preposição constitui elemento atrator da próclise de V2. Notemos que, nos casos acima, V1 é sempre um verbo cuja predicação exige preposição.

Estas ocorrências foram encontradas na $5^{\mathrm{a}}$ série (4 ocorrências) e $6^{\mathrm{a}}$ série (2 ocorrências) do Ensino Fundamental. Em todos estes casos, o clítico permanece posposto ao grupo verbal, de modo que podemos supor que, na verdade, o clítico é mais confortavelmente amalgamado ao verbo por meio do onset da silaba do clítico, e deste modo, dará preferência a 
este contexto, e assim, sempre que puder licenciar o onset da sílaba do clítico, isto será feito, de modo que podemos também supor que a preposição não geraria a restrição do onset.

600- Gostaria de encontra-la ... (6 $6^{\mathrm{a}}$ série);

665 - Gostaria de encontra-la amanha ... (6 $6^{\mathrm{a}}$ série);

706 - Gostaria de conhece-la ... (5 $5^{\mathrm{a}}$ série);

713 - Gostaria de conhece-la ... (5 $5^{\mathrm{a}}$ série);

752 - Quero ter o prazer de conhece-la ... (5ª série);

600- Gostaria de encontra-la ... ( $5^{\mathrm{a}}$ série).

Em relação ao clítico te, verificamos uma única ocorrência de ênclise no grupo verbal constituído de verbo + prep. + verbo em oposição ao que se encontra na língua falada (Pagotto, 1992)

441 - gostaria muito de conhecer-te ... (7 $7^{\mathrm{a}}$ série).

A única ocorrência do clítico “te” aparece em um grupo verbal em que verificamos uma preposição, o que constitui num contexto bastante favorável para que haja atração do clítico, o que causaria a interposição deste último no grupo verbal (proclítico a V2). A ocorrência 441 mostra o oposto disto: uma colocação, de certo modo, inesperada, o que remete novamente à hipótese da interferência da escola. É interessante notar que esta ocorrência, sendo um típico contexto que pediria a próclise a V2, conforme prescreve a norma aprendida na escola, é um caso de hipercorreção, conforme a hipótese de Silva (2007), pois o aluno opta pela posição que licenciaria o onset do clítico para uma forma que não traz esta exigência, ignorando a partícula atratora que antecede V2. Assim, o aluno corrige aquilo que naturalmente praticaria na fala, buscando uma adequação formal à norma exigida para a escrita. 


\subsubsection{3 Ênclise, onset silábico e assimilação}

As ocorrências do clítico o posposto a V2 infinitivo apresentam o onset do clítico licenciado (forma “la”). Neste contexto a realização das consoantes, mais precisamente, dos segmentos fônicos, está sujeita a uma regra de assimilação em que elementos de mesma identidade fônica se atraem ${ }^{15}$, e deste modo, reafirmamos as idéias de Nunes, 1993 (e Cordeiro, 2004) em que o tipo de fonema presente na terminação dos verbos constitui-se em traços de identidades semelhantes para que ocorra o onset do clítico, conforme o quadro que reproduzo abaixo:
i) vê-lo > ver + o
ii) fizemo-lo $>$ fizemos $+o$
iii) compararam-no > comparam + o

Percebemos, nos exemplos acima, que o onset da sílaba do clítico, por assimilação aos fonemas /r/ e /s/ (nas formas “ver” e "fizemos”) causa a supressão dos mesmos, e em iii), a nasalização da terminação /m/ também por assimilação, licencia o onset do clítico na forma “no”, de modo a manter a integridade fônica do segmento amalgamado ao verbo.

Os exemplos extraídos do corpus mostram V2 infinitivo preenchido pelos verbos “esperar” (6 ocorrências), “conhecer” (13 ocorrências), “encontrar” (4 ocorrências) e “ajudar” (1 ocorrência), combinados, em geral, com os verbos “querer" e "ir”. Em todas as ocorrências verificamos que ocorre o onset do clítico independente do contexto de interlocução ou dos elementos que interagem na estrutura argumental dos verbos. Concluímos, assim, que as terminações em /r/, /s/ e /m/ favorecem o emprego do clítico (em oposição ao seu

\footnotetext{
${ }^{15}$ Conforme Callou, 2001, um segmento fônico se realizará como sonora diante de uma sonora, como surda diante de uma consoante surda, e assim por diante.
} 
apagamento) uma vez que criam contexto para licenciamento do seu onset silábico. Nesses casos, ocorre a direção de cliticização fonológica da direita para a esquerda.

Entretanto, os exemplos 172, 174 e 438, com verbos simples, aparentemente contradizem a regra do licenciamento do onset da sílaba do clítico. Na verdade, estes exemplos constituem o que Silva (2007) classifica como hipercorreção.

Nos casos em que o clítico precede o verbo em posição inicial absoluta na sentença, a direção de cliticização ocorre da esquerda para a direita. É o que explica a predileção da próclise do clítico “te”. Entretanto, essa posição não licencia o onset do clítico “o”.

Os dois casos de interposição do clítico “o” referem-se a interposição deste no grupo verbal (anteposto a V2 infinitivo), correspondente às ocorrências 023 e 318 abaixo. Observese que a ausência de outros elementos interpostos ( [V1 cl X V2] ou [V1 cl X V2] ) não autoriza, nestes casos, a decidir pela ênclise ao $1^{\circ}$ verbo (queria, quero) ou pela próclise ao segundo verbo (conhecer).

023 - Queria a conhecer pois... ( $8^{\mathrm{a}}$ série)

318 - ...quero a conhecer. ( $7^{\text {a }}$ série)

Interessante notar que, para os alunos de Ensino Fundamental II, este tipo de construção não é usual. No entanto, encontramos estas duas ocorrências em séries em que a sintaxe começa a ser aprendida, o que, de certo modo, pode ter municiado o aluno a construir estas ocorrências. Notemos que, também nestes casos, há contexto que legitime o onset silábico do clítico, comportando-se como os casos de clítico posposto ao grupo verbal com V2 gerúndio.

Observemos agora o comportamento do clítico “o” quando há um grupo verbal com V2 no gerúndio. Constatamos neste único exemplo de ocorrência do clítico junto a um V2 gerúndio a forma “o” posposta ao grupo verbal (enclítica a V2) sem onset licenciado. 
016 - Não estou forçando-a a aceitar... (8ª série)

Observe-se que a permanência de ênclise a V2 se dá em contexto da presença do atrator (advérbio de negação). Saliente-se que este não se constitui em um contexto favorável ao licenciamento do onset silábico do clítico dado o fato de sua terminação ocorrer com uma vogal, não havendo, assim, a assimilação do traço característico necessário (identidade fonológica), permanecendo o clítico em sua forma vocálica.

Por fim, em relação aos grupos verbais, pode-se afirmar que o clítico ocupa predominantemente duas posições: uma intermediaria aos dois verbos e outra posposta a V2. Entretanto, há diferenças entre as combinações de forma nominal do verbo, a colocação e os tipos de clíticos que podem ocorrer nestas posições, criando-se uma escala implicacional:

i) Se V2 estiver no infinitivo, tem-se a ênclise a V2 = [V1 V2 cl]: neste contexto predomina o clítico “o”;

ii) Se V2 estiver no gerúndio, tem-se então [V1 cl V2]: esta posição aceita qualquer tipo de clítico;

iii) Se V2 estiver no particípio, tem-se então [V1 cl V2]: neste contexto predomina o clítico "te".

\subsubsection{Considerações finais sobre a modalidade informal}

A partir da análise empreendida até aqui, da parte do corpus correspondente à modalidade informal do discurso, percebemos a predominância dos clíticos para referência ao interlocutor, seguido do pronome tônico “você”, com um percentual bastante inferior, além do considerável crescimento do uso dos clíticos ao longo das quatro séries do Ensino 
Fundamental, havendo, neste contexto, uma evidente prevalência da forma "te” $(84,4 \%)$ sobre as forma “o” (11,3\%) e "Ihe” (4,3\%). Constatou-se, também, nas ocorrências da forma clítica “te”, que somente esta ocorre em estruturas que combinam V1 auxiliar + V2 particípio, e fato semelhante não se observou na modalidade formal do corpus analisado. Verificamos também que na modalidade informal, prevalece, em números bastante altos, a próclise para todas as formas de pronome clítico (acima dos 90\%).

Na análise dos clíticos antepostos a verbos simples em primeira posição na sentença, na forma $[\mathrm{cl} \mathrm{V}]$, verificamos que a não realização da ênclise, tal como constatado nas ocorrências a seguir.

172- a achei muito bonita. ( $8^{\mathrm{a}}$ série);

174- a espero até o anoitecer.(8a série);

438 - a achei muito bonita. ( $7^{\mathrm{a}}$ série).

Isto culmina em um caso de hipercorreção, em conformidade com a hipótese de Silva (2007), pois não há nenhuma partícula atratora no inicio da sentença, assim como os casos do clítico interposto ao grupo verbal com V2 no infinitivo (correspondente à estrutura [V1 cl V2]), que também são casos de hipercorreção, principalmente com a forma “o”, uma vez que o V2 infinitivo é um contexto propício para que o onset seja licenciado na posição enclítica, o que não ocorre, como é possível perceber nas ocorrências abaixo:

023 - Queria a conhecer pois... (8 ${ }^{\mathrm{a}}$ série);

318 - ...quero a conhecer. ( $7^{\mathrm{a}}$ série).

O mesmo ocorre em 441, pois há, nesta ocorrência, um elemento atrator de próclise, a preposição “de”, no entanto o clítico permanece enclítico a V2.

441 - gostaria muito de conhecer-te ... (7ª série). 
Observamos também que, para os clíticos “te" e "lhe”, prevalece a interposição ao grupo verbal, consolidando a estrutura [V1 cl V2], e para o clítico “o”, prevalece a posposição em relação ao segundo verbo, configurando-se assim na estrutura [V1 V2 cl] demonstrando, assim, um comportamento bem diferente ao observado nas outras formas clíticas.

\subsection{Duplicação do objeto}

Outro fato que merece menção, que não foi citado até aqui são as ocorrências de duplicação do objeto direto. Ao todo, foram 3 ocorrências na $5^{\mathrm{a}}$ série, 2 ocorrências na $6^{\mathrm{a}}$ série e 1 ocorrência na $7^{\text {a }}$ série, as quais reproduzimos logo a seguir para, sobre este fenômeno, tecer alguns comentários.

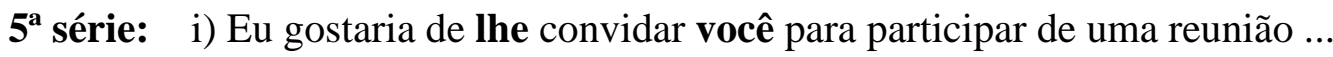

ii) Para tanto, quero te convidar o deputado para participar de uma reunião...

iii) Gostaria de lhe convida-lo para participar de uma reunião...

6 $^{\text {a }}$ série: iv) nós o ouvimos o senhor dizer muitas vezes que é importante ... v) nós o receberemos o senhor com um café da manhã...

7ª́rie: vi) Outro motivo interessante é o de te encontra-lo e debater sobre os assuntos.

Os casos de duplicação são interessantes, pois não se constituem como meros erros cometidos pelos alunos ao produzir um enunciado. Constituem-se em casos de hipercorreção $^{16}$, conforme veremos de modo mais amplo ao final deste capítulo. A

\footnotetext{
${ }^{16}$ Adotamos aqui o conceito de hipercorreção, em oposição ao conceito de erro, tal como formulou Silva (2007).
} 
hipercorreção, neste caso, parte, de certo modo, do conceito de morfologia estilística (Kato, 1994) que pressupõe que a exposição a um certo input ${ }^{17}$, diferente daquele adquirido como língua materna, faz com que um indivíduo faça uso de um determinado termo ou construção lingüística, impulsionado por forças extralingüísticas, ou seja, motivado pelo desejo de expressar um outro nível de linguagem, um padrão considerado socialmente aceito, o que significa que o aluno, quando aprende os clíticos, não os recupera como parte de um sistema de representação de língua internalizada.

Da mesma forma, a hipercorreção ocorre neste contexto, pois o aluno preocupa-se com a utilização de uma forma que não é natural ao seu sistema, e o faz preocupado com o cumprimento da exigência de comunicar-se adequadamente a um contexto de elocução formal, tal como o processo de escolarização prescreve. Exploraremos melhor estes tópicos ao final deste capítulo, pois, para esta discussão, a modalidade informal tem bastante a acrescentar.

É interessante observar, ainda, uma única ocorrência de duplicação do objeto direto (em número bem menor que na modalidade formal) encontrada na $5^{\mathrm{a}}$ série da modalidade informal do discurso, conforme reproduzimos abaixo.

vii) Ontem, eu a vi você no clube, conversando com suas amigas.

Este também é um contexto em que observamos a hipercorreção, em que o uso do clítico, aparentemente, funciona como morfologia estilística, pois o aluno sentiu a necessidade de preencher, ainda, com a forma tônica você, mostrando que, neste caso, o clítico “o” está apenas demonstrando a tentativa de alcançar um uso correto das formas na escrita.

\footnotetext{
${ }^{17}$ Entrada do conjunto de informações lingüísticas que chegam a um sistema, consolidando-o como tal.
} 


\subsection{Hipercorreção e Erro}

Na dissertação de Silva (2007), observamos uma interessante diferenciação para os desvios gramaticais e as produções de sentenças (ou de expressões internas a estas) não-usuais na língua portuguesa, que certamente podem orientar a análise empreendida até aqui. Consiste na diferenciação de tais desvios em hipercorreção ou erro, propriamente dito. Hipercorreção (ou ultracorreção) consistiria em um desvio ocasionado pela preocupação em produzir um enunciado (na escrita ou na fala) correto, definido como uma forma de bom uso da língua, de modo a fugir das variantes lingüísticas consideradas pouco prestigiadas para uma situação formal de interlocução. Isto ocorre, sobretudo, quando o indivíduo é exposto à norma gramatical, prescrita pela escola.

Nesse contexto, o falante ainda não domina a norma gramatical a que foi exposto nas aulas de gramática, mas julga estas formas adequadas, o que entra em conflito com a gramática de que já faz uso, adquirida em tenra idade, culminando, por vezes, na correção daquilo que estava correto. Assim, conforme a autora, hipercorreção pode ser considerada como uma “deformação do uso lingüístico correto".

A noção de erro, por contraste, passa a ser então a simples produção de sentenças ou expressões agramaticais, mal formadas, que não seriam aceitas como usuais em nenhuma variedade lingüística, seja na modalidade formal ou informal, seja na língua falada ou escrita. Neste contexto, o erro consistiria no uso de uma linguagem formal que não é familiar ao falante, no esforço de produzir um enunciado que não lhe é natural, a partir da imposição de uma convenção lingüística a que foi exposto, mas não dominou, sem que tenha a consciência da agramaticalidade daquilo que produziu, ou tenha sido motivado pela preocupação de falar bem ou escrever bem, como forma de fugir de uma variante socialmente estigmatizada. 
Deste modo, consideramos neste estudo, hipercorreção todo uso do pronome clítico (conforme já relatado) que parte da noção que o falante tem de sua própria língua, da língua falada, que lhe é familiar e corrente, e tenta adequá-la à norma gramatical prescrita na escola, de modo a não se adequar nem a um, nem a outro.

Assim sendo, os casos de hipercorreção encontrados neste estudo nos direcionam a uma reflexão sobre uma possível reanálise no estatuto gramatical do PB, mais especificamente, no sistema pronominal do $\mathrm{PB}$, pois temos o confronto entre o uso comum e corrente da fala, e a norma prescrita pela escola, em situações bastante peculiares, que demonstram diferentes formas pronominais clíticas imperando para cada contexto em que a referência ao interlocutor é requerida ao informante, conforme demonstrou a análise do corpus empreendida até aqui. Esta questão da reanálise será retomada na próxima seção.

\subsection{Especialização e Substituição de Formas}

Conforme as definições encontradas em Negrão \& Muller (1996), com relação ao estudo das categorias vazias e lexicais na posição de sujeito, e a distribuição das formas possessivas de $3^{\text {a }}$ pessoa (“seu” e “dele”) e Pereira (2005), em seu estudo acerca dos usos de “esse” e “este” no português brasileiro e o europeu, quando tratamos da questão da mudança lingüística, pode ocorrer o desaparecimento de uma determinada estrutura gramatical ou esta simplesmente pode passar a ser utilizada em um outro contexto lingüístico em que anteriormente não figurava. Neste panorama, definimos a possibilidade da existência de dois processos, e um deles certamente se adequará à explicação de uma mudança em curso. Um destes processos é o de substituição, que é utilizado para justificar hipótese de Pereira (op. cit.) sobre as referidas mudanças no PB com relação ao uso dos demonstrativos "este” e 
“esse”, e o outro é o processo de especialização, utilizado no estudo de Negrão \& Muller (op. cit.), para justificar a coexistência de suas formas pronominais no sistema gramatical do PB, sem que tenha havido o desaparecimento de uma em detrimento de outra, e assim seja possível constatar-se a coexistência de duas formas em um mesmo sistema.

Deste modo, a definição que utilizaremos é a mesma aventada por Pereira, de que ambos os conceitos de substituição e especialização de formas são processos opostos e somente podem ser verificados quando há a estabilização de um dado sistema gramatical em análise após iniciado um processo de mudança na língua. Assim, caracterizamos a substituição de formas como um processo pelo qual um termo passa a ser utilizado, ao longo do tempo, no lugar de outro, até que este último desapareça por completo, e caracterizamos especialização de formas como o processo pelo qual uma forma que antes era utilizada em um determinado contexto passa a ser utilizada em outro contexto, sem que a forma anteriormente utilizada e que caiu em desuso desapareça. Em outras palavras, uma estrutura gramatical qualquer cai em desuso e, aos poucos, encontra uma nova função dentro do sistema.

No entanto, é importante notar que, para que se caracterize uma especialização de formas é necessário que haja uma estabilização no sistema, que possa ser comprovada por meio de dados, uma vez que somente a observação o comportamento dos elementos integrantes a um determinado sistema lingüístico em um determinado período de tempo pode atestar ou não a estabilização das formas em uma gramática, mesmo que haja um contexto de resistência ${ }^{18}$.

Assim sendo, defendemos em nosso estudo, a partir da análise das diferentes proporções de ocorrência dos clíticos “te” e “o” em cada uma das situações de interlocução proposta para a realização do objeto direto, quando feito na forma de pronome clítico, que

\footnotetext{
${ }^{18} \mathrm{O}$ contexto de resistência pode levar a uma presunção de especialização de formas precipitada, pois pode acontecer o caso de uma forma que está em processo de substituição por outra manter durante um certo período de tempo certa produtividade, até que caia em desuso completamente. O problema consiste no fato de não ser possível precisar o tempo que leva para uma forma substitui outra em um dado sistema lingüístico, pois neste caso deve ser levados em consideração fatores extralingǘsticos.
} 
estamos diante de um contexto de reanálise do PB, em que a forma "te" passa a se especializar na $2^{\mathrm{a}}$ pessoa do discurso, no uso informal, enquanto a forma “o” especializa-se também na referência à $2^{\mathrm{a}}$ pessoa, só que em situações formais de interlocução.

Para apoiar esta hipótese, podemos recorrer ainda à tese de Ramos (1999), em que verificamos que na entrada da forma "você” em substituição de “tu”, a forma "te” passa a acompanhar "você” nas situações que pressupõem intimidade e informalidade, e, com a queda da forma "o" na terceira pessoa (Duarte, 1986), este clítico passa a se especializar também na referência à $2^{\mathrm{a}}$ pessoa (interlocutor) nas modalidades discursivas que exigirem maior formalidade no tratamento ao interlocutor, em um contexto em que não há mais concorrência e, sim, uma nova distribuição das formas pronominais clíticas em questão. 


\section{CONSIDERAÇÕES FINAIS}

Os resultados dos testes nos fazem inferir que estamos diante de uma reorganização do sistema pronominal e que a noção de correspondência entre os pronomes proposta pelas gramáticas normativa e descritiva não explica a escolha das formas. A realização da função acusativa em referência ao interlocutor é dependente não de questões gramaticais, mas do registro do discurso. As duas formas usadas na função de objeto direto são "te” e "o” para os registros informal e formal, respectivamente. Esses resultados contradizem nossa expectativa inicial de que a forma clítica “o” também estaria em desuso em referência ao interlocutor e de que a forma "Ihe” seria a opção para o registro formal. Obtivemos, portanto, o seguinte quadro pronominal para a função acusativa em referência ao interlocutor:

Função acusativa em referência ao interlocutor: Português Paulista

\begin{tabular}{|l|c|c|}
\hline & Estilo Formal & Estilo Informal \\
\hline Forma acusativa & $\mathrm{O}$ & $\mathrm{TE}$ \\
\hline
\end{tabular}

Deste modo, o que se verifica é a especialização de formas por meio do processo de reanálise. A forma “te”, conforme os resultados do trabalho aqui realizado, mantém-se na referência ao interlocutor nas situações informais do discurso, enquanto a forma “o” está se especializando na referência ao interlocutor no registro formal do discurso, o que vem a esclarecer um ponto bastante importante: ainda que o uso do clítico acusativo de $3^{\mathrm{a}}$ pessoa seja residual no PB (Duarte 1986), os dados analisados neste trabalho levam a inferir que a entrada de "você" no sistema não provocou - na variedade do português paulista - o desaparecimento completo do clítico acusativo “o”. Também não se pode falar em 
substituição de “o” por “lhe”, em concorrência com “te”, em relação ao interlocutor, hipótese avençada por Ramos (1999), mas sim em especialização de “o” como clítico acusativo em situações formais de interlocução.

Os resultados também revelaram um substancial aumento do uso do clítico na referência ao interlocutor ao longo das séries do Ensino Fundamental, o que indica que a escola municia o aluno com as formas pronominais desconhecidas da gramática internalizada. Se considerarmos o insucesso obtido em relação ao uso do clítico de $3^{\mathrm{a}}$ pessoa (Cordeiro, 2004) e a recuperação do clítico “o” em relação ao interlocutor, podemos inferir que a aprendizagem da gramática é orientada pelo uso formal e informal da língua. Esses resultados confirmam a hipótese de Kato (1999), segundo a qual o processo de aprendizagem envolve uma morfossintasse estilística.

Com relação à posição ocupada pelos clíticos na sentença, em relação ao verbo, notamos que somente o clítico "te" ocorre na estrutura [V1 +V2 particípio]. A forma "o" prevalece na posição posposta ao grupo verbal em que V2 é infinitivo, configurando a estrutura [V1 V2 cl], independente da presença de elementos atratores, assim como os clíticos “te” e "Ihe” ocupam prevalentemente a posição interposta aos grupos verbais, consolidando a estrutura [V1 cl V2] nos casos em que V2 é infinitivo ou gerúndio.

No que concerne à colocação pronominal, identificamos um caso de hipercorreção:

441 - gostaria muito de conhecer-te... ( $7^{\mathrm{a}}$ série)

A estrutura [V1 cl V2] é a preferida pelo clítico “te” nas modalidades falada e escrita da língua. Entretanto, no exemplo acima, em que há inclusive a presença de um elemento atrator de próclise (a preposição “de”) o clítico aparece em posição enclítica a V2. Trata-se de um caso de hipercorreção, pois este é o contexto que licencia o clítico “o”, elemento pronominal aprendido via instrução escolar. 
Outro processo de hipercorreção reside no uso da estratégia recorrente na língua falada. Trata-se da próclise observada no exemplo abaixo:

i) A achei muito bonita.

A estratégia interna à gramática nuclear (próclise) é preservada e o uso do pronome “te” ou “o” é uma mera escolha de um item lexical. O problema com o exemplo acima é que no PB o clítico acusativo de $3^{\mathrm{a}}$ pessoa precisa ocorrer em contexto que licencie o onset da sílaba do clítico, o que não ocorre no exemplo acima.

Nos dois casos de hipercorreção, há tentativa de adequação ao português correto.

Notamos ainda a existência de duplicações do objeto direto na referência ao interlocutor. Em todos os casos abaixo (já mencionados no capítulo anterior) o clítico é duplicado por uma forma pronominal tônica (“você”), por um pronome de tratamento (“o senhor”) ou por uma forma nominal de tratamento (“o Secretário”):

ii) Ontem, eu a vi você no clube ( $5^{\mathrm{a}}$ série);

iii) Eu gostaria de lhe convidar você ( $5^{\mathrm{a}}$ série);

iv) Quero te convidar o Secretário ( $5^{\mathrm{a}}$ série);

v) Nós o ouvimos o senhor dizer... (6 $6^{\mathrm{a}}$ série);

vi) Nós o recebemos o senhor com um café.. (6 $6^{\mathrm{a}}$ série).

As duplicações envolvem as três formas clíticas (“o”, "te”, “lhe”) e estão pautadas na língua falada, haja vista a existência inclusive de músicas em que se recuperam formas como “Eu te amo você”. Há, entretanto, formas que constituem erros visto que não são registradas no vernáculo: 
vi) Gostaria de lhe convida-lo... (5 $5^{\mathrm{a}}$ série);

viii) Outro motivo interessante é o de te encontra-lo ( $7^{\mathrm{a}}$ série).

Nos casos acima, não se pode falar em duplicação pronominal, pois as duas formas são clíticas. Além de essas formas não aparecerem na língua falada, observamos que nos dois casos o segundo clítico ocorre após um verbo no infinitivo, o que pode ser uma associação que o aluno faz entre este tipo de clítico e a forma nominal responsável pelo seu licenciamento.

Por fim, gostaríamos de salientar que a especialização de “o” em referência ao interlocutor no contexto de interlocução formal foi observada em textos escritos pelos alunos do Ensino Fundamental. Resta saber se na interlocução formal da modalidade falada da língua o clítico “o” se mantém ou se o falante recupera o clítico "Ihe”, conforme a proposta de Ramos (1999) e Oliveira (2004). 
AVERBURG, M. Objeto direto anafórico e sujeito pronominal na escrita de estudantes. Rio de Janeiro, Dissertação de mestrado: UFRJ, 2000.

BECHARA, E. Moderna Gramática Portuguesa. Ed. Lucerna, Rio de Janeiro, 2004.

BERLINCK, Rosane The Portuguese dative. In William Van Belle e Willy Van Langendonck. The Dative, vol.1, Amsterdam: John Benjamins, 1996.

BERLINCK, Rosane. Sobre a realização do objeto indireto no português do Brasil. Comunicação apresentada no II Encontro do Círculo de Estudos Lingüísticos do Sul - Celsul, Florianópolis, 1997.

CALLOU, Dinah e Yonne Leite. Iniciação à Fonética e Fonologia. Rio de Janeiro, Jorge Zahar Ed., 2001.

CÂMARA JUNIOR, Joaquim Matoso. Dispersos. Nova edição revisada e ampliada. Rio de Janeiro, Lucerna, 2004.

CHOMSKY, N.. Lectures on Government and Binding. Dordrecht: Foris (2a ed.1982) 1982. Some Concepts and Consequences of the Theory of Government and Binding.Cambridge: MIT Press,1981.

CHOMSKY, N. Knowledge of language. New York, Praeger, 1986.

CORDEIRO, Roseli. A aprendizagem do clítico acusativo de 3a. pessoa. Dissertação de mestrado, Universidade de São Paulo, São Paulo, 2004.

CORRÊA, V. Objeto direto nulo no português do Brasil. Dissertação de mestrado, UNICAMP, Campinas, 1991. 
CRUZ, Adilson Góis da. A expressão do argumento dativo no português escrito: Um estudo comparativo entre o português brasileiro e o português europeu. Dissertação de Mestrado. Universidade de São Paulo, São Paulo, 2007.

CUNHA, Celso e CINTRA, Lindley. Nova Gramática do Português Contemporâneo. Nova Fronteira: São Paulo. 1985

CYRINO, S. M. L. "Observações sobre a mudança diacrônica no português do Brasil: objeto nulo e clíticos". In KATO, M. \& ROBERTS, I. (orgs.) Português brasileiro - uma viagem diacrônica. Campinas: Ed. UNICAMP, 163-175, 1993.

DUARTE, M. E. L. O clitico de terceira pessoa: uma forma em extinção? IX Anais de Seminários do GEL. (Grupo de Estudos Lingüísticos do Estado de São Paulo), 1984.

DUARTE, M. E. Variação e sintaxe: clítico acusativo, pronome lexical e categoria vazia no português do Brasil. Dissertação de mestrado, PUC, São Paulo, 1986.

DUARTE, M. E. L. "Clítico acusativo, pronome lexical e categoria vazia no português do Brasil". In TARALLO, F. (org.) Fotografias Sociolingüísticas. Campinas: Ed. da Unicamp, 1989.

DUARTE, M. E. L. "Do pronome nulo ao pronome pleno: a trajetória do sujeito no português do Brasil". In: ROBERTS, I. \& KATO, M. (orgs.) Português Brasileiro: uma viagem diacrônica. Campinas: Ed. da Unicamp, 107-128. 1993

DUARTE, M.E. A perda do princípio “evite pronome” no português brasileiro, Tese de doutorado, Unicamp, Campinas, 1995.

DUARTE, M.E. Ensino da língua em contexto de mudança. Cadernos do IV Congresso Nacional de Lingüística e Filologia, vol. IV, no. 12, 2001, p. 51-61.

FIGUEIREDO SILVA \& R. E. V. LOPES. Manual de Sintaxe.Florianópolis: Ed. Insular, 1999. 
FREIRE, G. Os clíticos de terceira pessoa e as estratégias para sua substituição na fala culta brasileira e lusitana. Dissertação de mestrado. Rio de Janeiro: UFRJ, 2000.

FREIRE, G. A realização do acusativo e do dativo anafóricos de terceira pessoa na escrita brasileira e lusitana. Tese de Doutorado. UFRJ, 2005.

GALVES, C.. Pronomes e Categorias Vazias em Português do Brasil. Cadernos de Estudos Lingüísticos, UNICAMP, nº 7, Campinas,1984

GALVES, C. "O enfraquecimento da concordância no português brasileiro." In KATO, M. \& ROBERTS, I (orgs.) Português Brasileiro - uma viagem diacrônica. Campinas: Ed. UNICAMP, pp. 387 - 403, 1993.

GALVES, C. "A gramática do português brasileiro". In Línguas. Instrumentos Lingüísticas. Pontes. 79-93, 1998.

GALVES, C. \& ABAURRE M. B. "Os clíticos no português brasileiro: elementos para uma abordagem sintático-fonológica". In CASTILHO, A. \& BASíLIO, M. (orgs.). Gramática do Português Falado. Vol IV. Estudos Descritivos. Campinas: Editora da UNICAMP. P.267312, 2002.

GIVON, T.. On Understanding Grammar. New York: Academic Press,1979.

GUASTI, M.T. e CARDINALETTI, A. Relative clause formation in Romance child's production. Probus, Dordrecht, vol. 15, pp. 47-88, 2003.

HAEGEMAN, L. Introduction to govemment and bindiog theory. Oxford (UK), Cambridge (MA): Blackwell, 1991.

HUANG, C. T. J.. On the Distribution and Reference of Empty Pronouns. Linguistic Inquiry, vol. 15, no. 4, 1984.

JACKENDOFF, R.. Semantic Interpretation in Generative Grammar. Cambridge: MIT Press, 1974. 
JAEGGLI, O.. Topics in Romance Syntax. Dordrecht: Foris. (29 Foris Ed. 1982), 1981.

KATO, M.. Orações Relativas: Variação Universal e Variação Individual no Português. V Anais de Seminários do GEL (Grupo de Estudos Lingüísticos do Estado de São Paulo), 1981.

KATO, M. Português Brasileiro falado: aquisição em contexto de mudança lingüística.In: I.Duarte e I.Leiria (orgs) Actas do Congresso Internacional sobre o Português. Vol II., 1996, p. 211-237.

KATO, M. Strong pronouns and weak pronominals and the null subject parameter. PROBUS, 11,1, 1999, p.1-37.

KATO, M. A. \& RAPOSO E. () "O objeto nulo definido no português europeu e no português brasileiro: convergências e divergências". In CORREIA, C. N. \& GONÇALVES, A. (orgs.) Actas do XVI Encontro Nacional da Associação Portuguesa de Lingüística. Lisboa: Associação Portuguesa de Lingüística, 2001.

KATO, M. A. "A gramática do letrado: questões para a teoria gramatical". In MARQUES,M. A., KOLLER, E., TEIXEIRA, J. \& LEMOS, A. S. (Org.). Ciências da Linguagem: 30 anos de investigação e ensino. Braga: CEHUM (Universidade do Minha), 2005.

LABOV, W. Sociolinguistic Patterns, Philadelphia, University of Pennsilvania Press, 1972.

LEMLE, M.. Heterogeneidade dialetal: um apelo à pesquisa. Linguistica e Ensino do Vernáculo. Rio de Janeiro: Edições Tempo Brasileiro, 1978.

LOPES, R. E. V. Uma Proposta Minimalista para o Processo de Aquisição da Linguagem: Relações Locais. Tese de doutoramento. Campinas, UNICAMP, 1999. 
LUCCHESI, D. Variação e Norma: Elementos para uma caracterização Sociolingüística do Português do Brasil. Revista Internacional de Língua Portuguesa, Lisboa, v. 12. p. 17-28, 1994.

MATEUS M.H.M. at al. Gramática da Língua Portuguesa. Coimbra: Libraria Almedina, 1983.

MEISEL Verbal Functional Categories in Early Grammatical Development: Evidence from Simultaneous Acquisition of the First Language: French and German - Ms. University of Hamburg, 1990.

MONTEIRO, J. L. Para compreender Labov. Petrópolis, RJ: Vozes, 2000.

MOLUCA, M. C.; BRAGA, M. L. O. (org.) Introdução à sociolingüística: o tratamento da variação. São Paulo: Contexto, 2004.

NEVES, M.H.M. A gramática de usos do Português .São Paulo: Editora Unesp, 2000.

NUNES, Jairo. "Direção de cliticização, objeto nulo e pronome tônico na posição de objeto em Português Brasileiro "in M. Kato \& I. Roberts (orgs.) Português Brasileiro: uma viagem diacrônica, Unicamp, Fapesp,1993.

NUNES, J. Direção de Cliticização, Objeto Nulo e Pronomes Tônicos na Posição de Objeto em Português Brasileiro. In ROBERTS, I. \& KATO, M. (Org.). Português Brasileiro: Uma Análise Diacrônica. 1.a ed. Campinas: Editora da UNICAMP, 1993.

NEVES, Maria Helena de Moura Gramática de Usos do Português. São Paulo: Ed. UNESP, 2000.

OLIVEIRA, Marilza (2004) A perda da preposição "a" e a recategorização do clítico "lhe", in Estudos Lingüísticos 33:292-297, cd-rom. 
OLIVEIRA, M. "A aquisição da preposição a no português como L2: complementos dativos". Boletim da Associação Brasileira de Lingüística (ABRALIN), 2005.

OMENA, N. P. de.. Pronome Pessoal de Terceira Pessoa: Suas Formas Variantes em Função Acusativa. Dissertação de mestrado. PUC, Rio de Janeiro,1978.

PAGOTTO, E. G. A posição dos clíticos em português: um estudo diacrônico. Dissertação de Mestrado. UNICAMP, Campinas, 1992.

PAGOTTO, E. "Clíticos, Mudança e seleção natural", in M. Kato \& I. Roberts (Orgs.) Português Brasileiro: uma viagem diacrônica, Ed. Unicamp, 1993

PEREIRA, Helcius Batista. “Esse” versus “Este” no Português Brasileiro e no Português Europeu. Dissertação de Mestrado. Universidade de São Paulo, São Paulo, 2005

PEREIRA, Ma das G. D.. A Variação na Colocação dos Pronomes Átonos no Português do Brasil. Dissertação de mestrado. PUC, Rio de Janeiro, 1981.

RAMOS, Conceição de Maria de Araújo. O Clítico de $3^{\mathrm{a}}$ pessoa: um estudo comparativo português brasileiro/espanhol peninsular. Tese de doutoramento. Universidade Federal de Alagoas, Maceió, 1999.

RAPOSO, Eduardo. Clitic Position and verb movement. In: COSTA, J. Portuguese Syntax: New Comparative Studies. Oxford: Oxford University Press, 1992

RAPOSO, E. Teoria da gramática. A faculdade da linguagem. Lisboa: Caminho, 1992b.

RODRIGUES, Â.C. S. Português Popular em São Paulo. In: Simpósio A Língua Portuguesa em São Paulo, 2004, São Paulo.

ROUVERET, A. Cliticização e tempo no português europeu. In Cadernos de Estudos Lingüísticos, no. 17, UNICAMP, p. 9-37. Campinas, 1989. 
RIZZI, L. 1986. Null Objects in Italian and the Theory of pro. Linguistic Inquiry, vol. $17, n^{\circ} 3$.

SILVA, Hosana dos Santos. A Aprendizagem do Pronome Relativo “Cujo”: Reflexões sobre a escrita. Dissertação de Mestrado. Universidade de São Paulo, São Paulo, 2007.

TARALLO, F \& M. A. KATO . Harmonia Trans-sistêmica: variação inter e intralingüística. Preedição, Campinas, n 5, pp. 315-353, 1989.

TORRES-MORAIS \& BERLINCK, R. A. "Caracterização do objeto indireto no Português". Trabalho apresentado no V encontro do PHPB. Outro Preto. MG, 2002.

TORRES-MORAIS, M. A"Aspectos diacrônicos do sistema pronominal do português brasileiro". In II Encontro Nacional do GELCO: Integração lingüística, étnica e social. Oficina Editorial do Instituto de Letras da UnB,191-197, 2004.

URIAGEREKA, J. Aspects of Syntax of Clitic Placement in Western Romance, ms, University of Maryland, EUA, 1995.

VOTRE, S. J. Relevância da variável escolaridade. In: MOLLICA, M. C.; BRAGA, M. L. O. (org.) Introdução à sociolingüística: o tratamento da variação. São Paulo: Contexto, 2004.

WEINREICH, U.; LABOV, W. ; HERZOG, M. Empirical foundations for a theory of language change. In: LEHMANN, W. \& MALKIEL, Y. (eds.) Directions for historical linguistics: a symposium. Austin: University of Texas Press, 1968, pp. 95-189. 